\title{
Care during labor and birth for the prevention of intrapartum-related neonatal deaths: a systematic review and Delphi estimation of mortality effect
}

Anne CC Lee ${ }^{1,2^{*}}$, Simon Cousens ${ }^{3}$, Gary L Darmstadt ${ }^{1,4}$, Hannah Blencowe ${ }^{3}$, Robert Pattinson ${ }^{5}$, Neil F Moran ${ }^{6}$, G Justus Hofmeyr ${ }^{7}$, Rachel A Haws', Shereen Zulfiqar Bhutta ${ }^{8}$, Joy E Lawn ${ }^{9}$

\begin{abstract}
Background: Our objective was to estimate the effect of various childbirth care packages on neonatal mortality due to intrapartum-related events ("birth asphyxia") in term babies for use in the Lives Saved Tool (LiST).

Methods: We conducted a systematic literature review to identify studies or reviews of childbirth care packages as defined by United Nations norms (basic and comprehensive emergency obstetric care, skilled care at birth). We also reviewed Traditional Birth Attendant (TBA) training. Data were abstracted into standard tables and quality assessed by adapted GRADE criteria. For interventions with low quality evidence, but strong GRADE recommendation for implementation, an expert Delphi consensus process was conducted to estimate causespecific mortality effects.
\end{abstract}

Results: We identified evidence for the effect on perinatal/neonatal mortality of emergency obstetric care packages: 9 studies (8 observational, 1 quasi-experimental), and for skilled childbirth care: 10 studies (8 observational, 2 quasi-experimental). Studies were of low quality, but the GRADE recommendation for implementation is strong. Our Delphi process included 21 experts representing all WHO regions and achieved consensus on the reduction of intrapartum-related neonatal deaths by comprehensive emergency obstetric care (85\%), basic emergency obstetric care (40\%), and skilled birth care (25\%). For TBA training we identified 2 metaanalyses and 9 studies reporting mortality effects ( 3 CRCT, 1 quasi-experimental, 5 observational). There was substantial between-study heterogeneity and the overall quality of evidence was low. Because the GRADE recommendation for TBA training is conditional on the context and region, the effect was not estimated through a Delphi or included in the LiST tool.

Conclusion: Evidence quality is rated low, partly because of challenges in undertaking RCTs for obstetric interventions, which are considered standard of care. Additional challenges for evidence interpretation include varying definitions of obstetric packages and inconsistent measurement of mortality outcomes. Thus, the LiST effect estimates for skilled birth and emergency obstetric care were based on expert opinion. Using LiST modelling, universal coverage of comprehensive obstetric care could avert 591,000 intrapartum-related neonatal deaths each year. Investment in childbirth care packages should be a priority and accompanied by implementation research and further evaluation of intervention impact and cost.

Funding: This work was supported by the Bill and Melinda Gates Foundation through a grant to the US Fund for UNICEF, and to Saving Newborn Lives Save the Children, through Save the Children US.

\footnotetext{
* Correspondence: aclee@jhsph.edu

'Johns Hopkins Bloomberg School of Public Health, Department of

International Health, Baltimore MD, USA

Full list of author information is available at the end of the article
}

(c) 2011 Lee et al; licensee BioMed Central Ltd. This is an open access article distributed under the terms of the Creative Commons 


\section{Background}

The remarkable decline in neonatal mortality rates in the middle of the 20th century in high income countries has been commonly credited to the advent of hygienic childbirth practices and modern obstetric care [1], with additional reductions since the 1970s attributed to increasingly intensive neonatal care. In low income countries, where skilled professionals attend fewer than half of deliveries, and each year 60 million births occur outside facilities [2], the burden of neonatal morbidity and mortality related to childbirth remains very high [3]. Intrapartum-related events in term babies associated with hypoxic injury (previously loosely termed "birth asphyxia") are responsible for an estimated 814,000 neonatal deaths [4] and also one million stillbirths [5] each year, with perhaps one million disabled survivors with long-term neuro-developmental injury, including cerebral palsy, mental retardation, blindness, long term intellectual impairment and behavioral problems [6,7]. Childbirth is also the time of greatest risk for maternal deaths with at least $42 \%$ of the annual estimated 352,000 maternal deaths occurring during labor and the first 2 days after birth $[3,8,9]$.

While skilled attendance at delivery and emergency obstetric care are the basis of modern obstetrics, there is remarkably limited impact evaluation. This gap is related both to methodological challenges such as the large sample sizes required for meaningful statistical comparisons, and also because many obstetric interventions were in routine practice before the advent of randomized controlled trials (RCTs), making it unethical, for example, to undertake a RCT of the impact of Caesarean section [10]. Estimates of the effectiveness of intrapartum care in reducing maternal and neonatal mortality and stillbirths are needed to inform healthcare planning and prioritization in low resource countries.

In this paper, we assess the evidence for effect on neonatal mortality of health service delivery packages during labor and childbirth. The terminology around childbirth care has been through various transitions in the last decade, and at times even different United Nations (UN) agencies use the same term differently [11]. Here, we have taken the latest UN consensus and reviewed the terminology for clarity (Table 1). Comprehensive emergency obstetric care (CEmOC) is the standard full package of obstetric care including Caesarean section and blood transfusion [12,13]. Basic emergency obstetric care (BEmOC) includes the six signal functions that should be available at first-level facilities which provide childbirth care: parenteral antibiotics, parenteral oxytoxics, parenteral anticonvulsants for pre-eclampsia or eclampsia, assisted vaginal delivery (including vacuum or forceps assistance for delivery, episiotomy, advanced skills for manual delivery of shoulder dystocia, skilled vaginal delivery of the breech infant), manual removal of the placenta, and removal of retained products [12-14]. Skilled childbirth care is defined by WHO as care provided by "an accredited health professional - such as a midwife, doctor or nurse - who has been educated and trained to proficiency in the skills needed to manage normal (uncomplicated) pregnancies, childbirth and the immediate postnatal period, and in the identification, management and referral of complications in women and newborns." [12,13] For the purpose of these estimates, the effect of skilled attendance is considered as the attendant without additional obstetric care functions (BEmOC or CEmOC). We also reviewed the evidence for childbirth care by community cadres providing care at birth, such as a Traditional Birth Attendant (TBA), defined by WHO as a person who "assists the mother during childbirth and who initially acquired her skills by delivering babies herself or though an apprenticeship to other TBAs" [15].

Emergency obstetric care coverage remains extremely low, especially in rural areas: only $5 \%$ of births in rural South Asia and 1\% in rural Sub-Saharan Africa are by Caesarean section [10]. Ensuring equitable coverage of skilled attendance may have been under resourced because it is considered complex and expensive [16]. If the impact of more complex childbirth care is high, then even given higher cost, the cost-effectiveness ratio may still be very favorable. There is a critical need for data regarding lives saved in order to inform investment choices and design effective programs. Skilled attendance coverage in Sub-Saharan Africa has increased little in the last decade. The Lives Saved Tool (LiST) has been designed to enable national (or sub-national) planning based on estimation of lives saved for mothers, neonates and children (http://www.jhsph.edu/dept/ih/ IIP/list/index.html). The tool comes with a menu of interventions that are linked to mortality effects, and the user can increase coverage of each intervention from a baseline rate to compare the impact and cost of different interventions at varying levels of coverage.

\section{Objective}

The objective of this review is to estimate the effect of different packages of care during labor and birth on intrapartum-related neonatal deaths in term babies, for inclusion in the Lives Saved Tool (LiST).

\section{Methods}

We followed a standard approach to searches, abstraction and evaluation of evidence as set out by the Child Health Epidemiology Group (CHERG) for effect estimates to be used in the LiST model [17]. More details of the review methods, the adaptation of GRADE, the rules for attribution of mortality effect, and the LiST model, are published elsewhere $[17,18]$. 


\begin{tabular}{|c|c|}
\hline $\begin{array}{l}\text { Comprehensive Emergency Obstetric } \\
\text { Care(CEmOC) }\end{array}$ & $\begin{array}{l}\text { Full package of CEmOC as per UN definitions }[12,14] \text {, includes all six BEmOC functions PLUS: } \\
\text { - Caesarean section } \\
\text { - Blood transfusion }\end{array}$ \\
\hline $\begin{array}{l}\text { Basic Emergency Obstetric Care } \\
\text { (BEmOC) }\end{array}$ & $\begin{array}{l}\text { UN definition of the } 6 \text { signal functions of BEmOC }[12,14] \\
\text { - IV/IM antibiotics } \\
\text { - IV/IM uterotonic drugs/oxytoxics } \\
\text { - IV/IM anticonvulsants for pre-eclampsia and eclampsia (ie. magnesium sulfate) } \\
\text { - Manual removal of placenta } \\
\text { - Assisted vaginal delivery (episiotomy, instrumental delivery (forceps or vacuum extraction), advanced skills } \\
\text { for manual delivery of shoulder dystocia, breech) } \\
\text { - Removal of retained products (manual vacuum extraction, dilation and curettage) } \\
\text { * Assuming no access to Caesarean section or blood transfusion }\end{array}$ \\
\hline Skilled childbirth care & $\begin{array}{l}\text { Skilled birth attendant defined by WHO, ICM, and FIGO as "an accredited health professional - such as a } \\
\text { midwife, doctor or nurse - who has been educated and trained to proficiency in the skills needed to } \\
\text { manage normal (uncomplicated) pregnancies, childbirth and the immediate postnatal period, and in the } \\
\text { identification, management and referral of complications in women and newborns." [13] } \\
\text { The core intrapartum skills that should be provided include: } \\
\text { - Clean delivery care } \\
\text { - Monitoring onset and progress of labor with partograph } \\
\text { - Monitoring maternal and fetal well-being during labor, identify maternal/fetal distress and taking } \\
\text { appropriate action including referral } \\
\text { - Manage normal vaginal delivery (including releasing a cord around the neck, delivery of shoulders, assisting } \\
\text { a breech delivery) } \\
\text { - Active management of third stage of labor } \\
\text { - First line management of hemorrhage and hypertension in labor, referral as needed } \\
\text { - Pain relief, hydration } \\
\text { * For the purposes of this estimate assuming no access to instrumental delivery (forceps or vacuum } \\
\text { extraction), Caesarean section or blood transfusion }\end{array}$ \\
\hline Trained Traditional Birth Attendant & $\begin{array}{l}\text { Traditional birth attendant defined by WHO as "a person who assists the mother during childbirth and who } \\
\text { initially acquired her skilled by delivering babies herself or through an apprenticeship to other TBAs"[15]. A } \\
\text { "trained TBA" is "any TBA who has received a short course of training through the modern health sector to } \\
\text { upgrade her skills" [61]. TBAs may range from family members attending only occasional births to women } \\
\text { with considerable expertise attending } 20+\text { births/year. TBAs are not usually salaried, and typically not civil } \\
\text { servants or employed by Ministry of Health. }\end{array}$ \\
\hline
\end{tabular}

\section{Timing of intervention and effect:}

These packages include care provided during labor and birth, but in order to be effective, the care may have been initiated during the antenatal period (e.g., screening for abnormal lie and decision for elective Caesarean section, or screening and management of hypertensive disease of pregnancy/eclampsia). Some interventions are primarily intrapartum in timing such as management of acute intrapartum events including antepartum hemorrhage, cord prolapse and obstructed labor.

\section{Not included in these effect estimates:}

The effects on neonatal survival of specific interventions after birth for the baby are not included here as they are treated as single additional interventions in LiST and have been considered in detail in other reviews:

- Stimulation and neonatal resuscitation at birth,

- Postnatal healthy practices (breastfeeding, hygienic cord and skin care, thermal care).

In addition, a few specific obstetric interventions which are in LiST but affect other neonatal causes of death have been considered in detail in other reviews including the following:

- Corticosteroids for preterm labor (affects preterm deaths),

- Antibiotics for preterm premature rupture of membranes (affects deaths from infections).

\section{Searches for intervention evidence}

We undertook systematic searches of published literature from 1980 until March 2010. The original search was part of two parallel comprehensive literature reviews assessing the impact of intrapartum childbirth care on stillbirth [19-21] and intrapartum-related neonatal mortality [10]. The following databases were searched without language restrictions until March 2009: PubMed, POPLINE, Cochrane, EMRO, LILACS, and AIM (figures 1,2). The search terms included
MESH combinations of "skilled birth attendant," "midwifery," "basic/comprehensive emergency obstetric care," "traditional birth attendant," AND "birth asphyxia," "asphyxia neonatorum," or "neonatal-perinatal mortality." A second updated search was conducted in March 2010 that required "skilled birth attendant," "midwifery," "emergency obstetric care," "traditional birth attendant" AND "neonatal OR perinatal mortality." Snowball searching, whereby literature referenced in key papers was included, was also employed. 


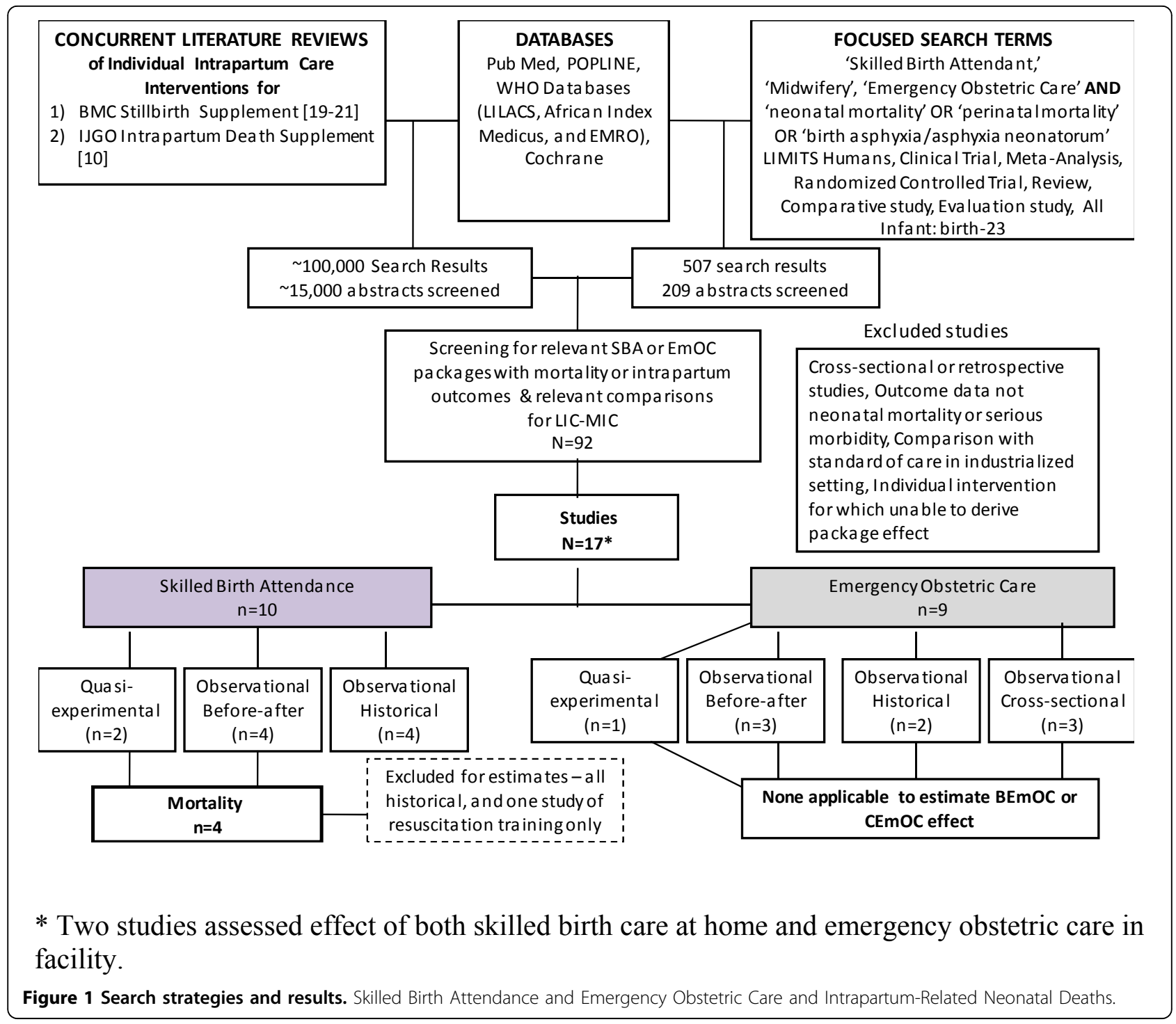

\section{Inclusion/exclusion criteria}

Data from studies meeting the inclusion criteria were extracted using a standard form (Additional File 1). We assessed the quality of each study using a standard approach developed by the Child Health Epidemiology Reference Group (CHERG) [17].

We applied the PICO format (Patient, Intervention, Comparison, and Outcome) to define the studies to be included as follows. The population of interest was pregnant women, or those in labor.

\section{Intervention definitions and those not considered in this review}

The interventions considered are childbirth care packages and TBA training, as defined in Table 1. The study intervention was considered to meet package criteria [22] if 1) the authors directly described the intervention using package terminology (eg. BEmOC or $\mathrm{CEmOC}$ ), or 2) the majority of package functions were reported to have been provided.

The effects of other interventions around childbirth are considered in separate reviews. While specific interventions, such as clean delivery practices and neonatal resuscitation, are considered essential elements of skilled birth attendance and emergency obstetric care, the effects are estimated separately in the LiST tool and reviewed in other papers $[23,24]$. The effects of individual childbirth interventions (such as fetal monitoring, partograph, labor induction, or Caesarean section), were reviewed separately in two concurrent supplement reviews published elsewhere and are not detailed again here $[10,20,21]$. In addition, those interventions specifically targeting the prevention of deaths due to preterm complications, even if provided during the intrapartum period, are not 


\section{b. Traditional Birth Attendants}

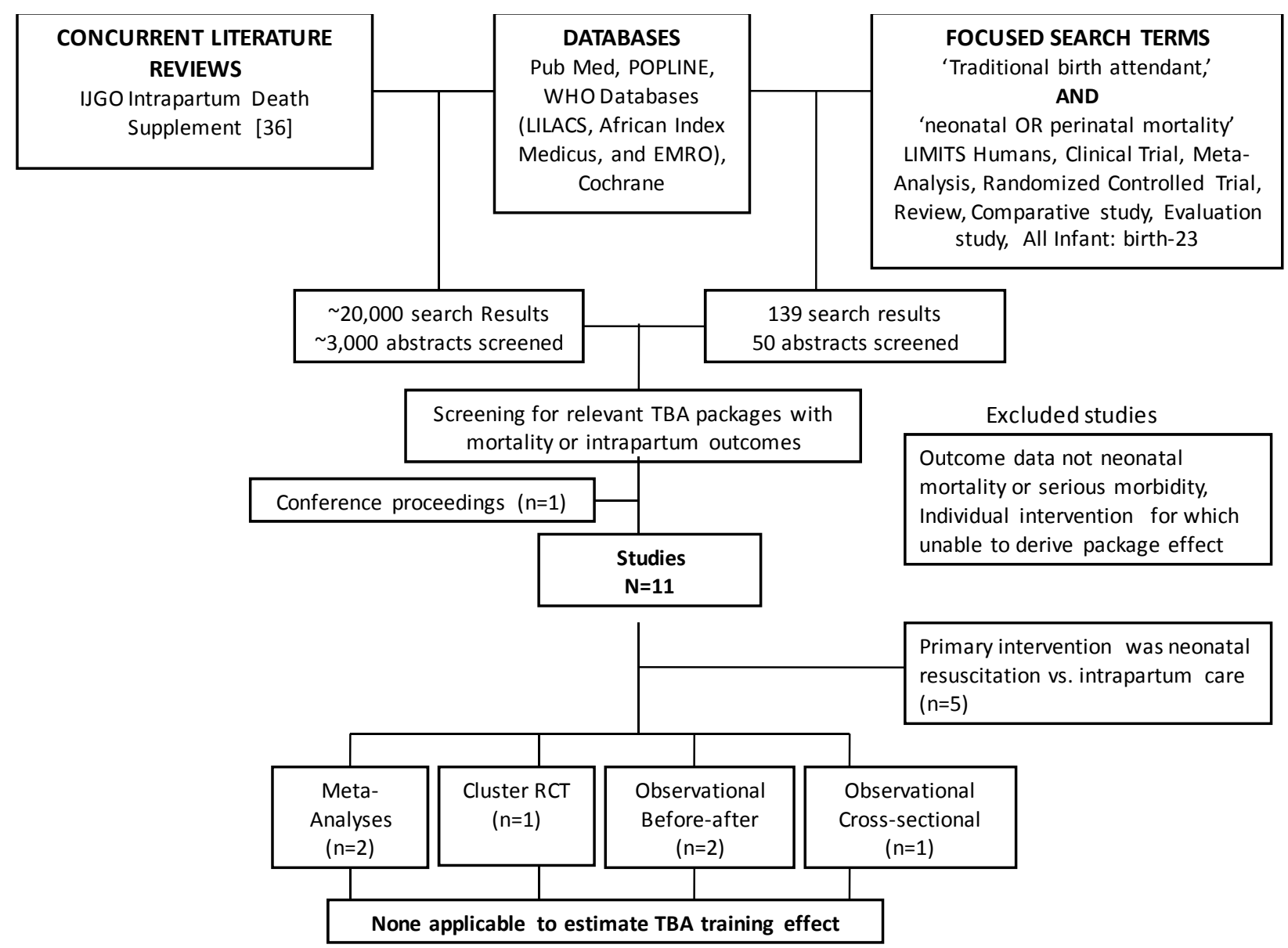

Figure 2 Search strategies and results. Traditional Birth Attendants.

considered here, such as corticosteroids for prevention of preterm labor and antibiotics for preterm PROM) $[25,26]$.

\section{Comparison group}

In LiST the counterfactual is no care at all. Clearly a randomised trial with no skilled care provided at birth would be considered unethical, and most evaluations are non-randomised where the comparison is with standard practice. Hence we included studies with other comparison groups, such as before/after studies of improvements to existing services, cross-sectional and casecontrol studies, and historical data that reported mortality impact over several decades, recognizing that the majority of these studies did not control for confounders and were thus potentially subject to substantial bias.

\section{Outcome definitions}

A neonatal death was defined as a death in the first 28 days of life, early neonatal death as death in the first 7 days of life, and perinatal death as a stillbirth $(>1000$ gms, $>28$ weeks gestation) or death in the first $\overline{7}$ days of life. Deaths due to any cause are referred to as all cause mortality and intrapartum-related neonatal death classifies babies who die from childbirth related hypoxic events, (ie. what was previously referred to as "birth asphyxia"). While the term "birth asphyxia" has been used to describe babies who do not breathe at birth, the term is no longer recommended for epidemiological use in cause-of-death attribution [5,27]. Intrapartum-related neonatal mortality is defined by CHERG, based on ICD 10 rules and recent global consensus statements, as term babies who die after neonatal encephalopathy, or death prior to onset of neonatal encephalopathy, with evidence of intrapartum injury or acute intrapartum events [5,27]. Neonatal encephalopathy (NE) may directly result from intrapartum hypoxia and is considered a predictive marker of long term morbidity and mortality [3]. NE is defined as a "disturbance of 
neurological function in the earliest days of life in the term infant manifested by difficulty initiating and maintaining respiration, depression of tone and reflexes, abnormal level of consciousness and often by seizures [28,29]." Hypoxic Ischemic Encephalopathy is the condition of neonatal encephalopathy following severe hypoxic injury, however, is not recommended unless there is clear evidence of sufficient hypoxemia to account for impaired brain function [30].

We also examined studies that reported all cause neonatal mortality or specific morbidity, notably NE. We did not examine Apgar score as an outcome since our goal was to establish mortality effect estimates and the Apgar score is considered to be an unreliable indicator of mortality [31]. The effects of intrapartum care on stillbirths and maternal outcomes are also important and are reviewed elsewhere in this supplement [32].

\section{Ecologic analysis of variation in neonatal encephalopathy incidence}

Given the paucity of direct evidence of package impact, we also conducted an ecological analysis to examine the relationship between NE incidence and coverage of childbirth care, drawing on a systematic review for the Global Burden of Disease Project, undertaken with the Child Health Epidemiology Reference Group [33]. In brief, PubMed, POPLINE, Cochrane, EMRO, EMBASE, LILACS, and AIM databases were searched using the terms "neonatal encephalopathy" and "hypoxic ischemic/ ischemic encephalopathy" (figure 3). All titles were reviewed and articles were retrieved that had data on incidence, case fatality rates or chronic impairment. Potentially relevant country covariates, including \% skilled attendance, \% facility delivery, and \% Caesarean section, were obtained from UN databases [2]. The natural $\log$ of the neonatal encephalopathy incidence rate was regressed on each obstetric indicator of interest using simple linear regression.

\section{Delphi Process for establishing expert consensus}

For interventions with low or very low quality evidence but strong recommendation for program implementation $[34,35]$, as per CHERG rules for LiST effect estimates, we sought expert consensus via the Delphi method [36]. We invited a panel of experts in obstetrics, gynecology and newborn health from all WHO regions and including multiple disciplines - program management, research, clinical obstetrics, and general paediatrics. The questionnaire was developed by JL, ACL, NM and GLD through several rounds of pilot testing. The survey was sent by email and included the background and aims of the Delphi process, evidence identified, and requested seven different effect estimates (Additional File 2). Respondents were allowed the option of anonymous response. The median response and range were determined for each question. Consensus was defined a priori as having been achieved when the interquartile range of responses to a given question was $\leq$ $30 \%$. For those estimates not reaching consensus on the first round, the results were electronically distributed to the panel, virtual discussion allowed, and a second round of email questionnaires sent.

\section{Analyses and summary measures}

We conducted meta-analyses for mortality outcomes [neonatal mortality rate (NMR), perinatal mortality rate (PNMR), and early neonatal mortality rate (ENMR)] of observational before-after studies of community-based skilled birth attendants. Studies were considered for inclusion in the meta-analysis that had comparable intervention, study design, and outcome of interest. Statistical analyses were performed using STATA 10.0. The Mantel-Haenszel pooled risk ratio (RR) - or where there was evidence of heterogeneity $(\mathrm{p}<0.05)$, the DerSimonian-Laird pooled RR - and 95\% confidence interval (CI) were calculated. For the Delphi panels, expert estimates were entered in an Excel spreadsheet and simple descriptive statistics were produced.

\section{Results}

The search strategies and results are summarised in figures 1,2 . From the combined searches for skilled birth attendance and emergency obstetric care, which yielded around 15,000 abstracts, we retrieved 92 papers, reports or conference abstracts for full text review. From these, 17 studies reporting outcomes and comparisons of interest were identified. For the combined searches for traditional birth attendants, a total of around 3000 abstracts were identified, yielding 11 articles of interest.

\section{Results of literature review Emergency obstetric care}

Overall, few studies presented comparisons of childbirth care packages consistent with the UN definitions (table 1). The 9 studies of emergency obstetric care packages reporting neonatal mortality outcomes identified for this review were low quality and heterogeneous in terms of intervention content (Table 2), and not suitable for meta-analysis or for the LiST mortality effect estimation.

We identified one study that compared basic and comprehensive emergency obstetric care with no skilled care with respect to neonatal mortality outcomes [37]. Ronsmans and colleagues analyzed health and demographic surveillance system data from 1987-2005 in Matlab, Bangladesh to examine the relationship between the use of BEmOC and CEmOC with early neonatal mortality and stillbirth [37]. They found that women receiving $\mathrm{BEmOC}$ and $\mathrm{CEMOC}$ had a higher risk of 


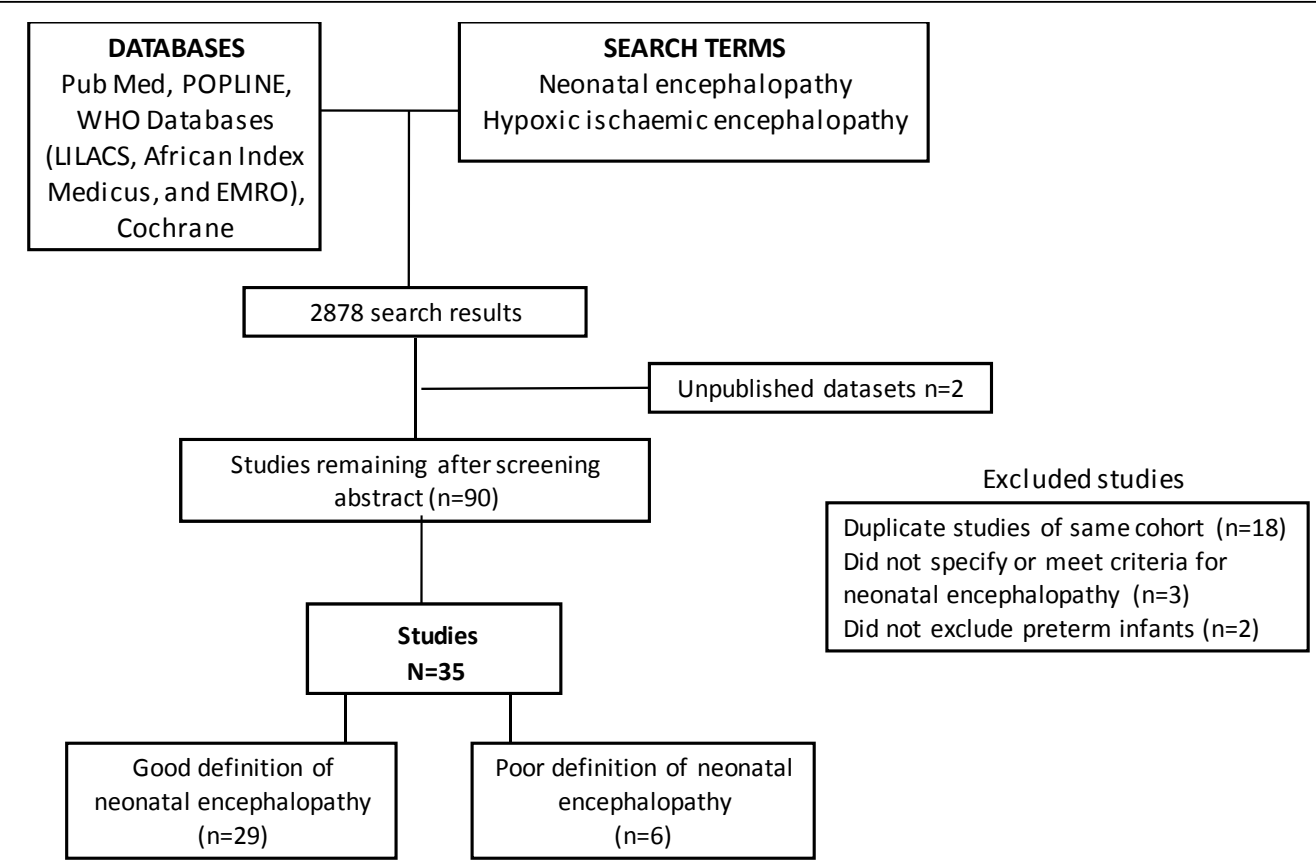

Figure 3 Search strategies and results. Incidence of neonatal encephalopathy.

early neonatal mortality (BEmOC aOR $1.47,95 \% \mathrm{CI}$ 1.27-1.69; CEmOC aOR 2.69, 95\% CI 2.16-3.37) compared to mothers delivering at home without skilled care. However this observational study is prone to selection bias, as skilled care/emergency obstetric care was likely sought for higher-risk, complicated deliveries, and thus the observed association is unlikely to reflect the population effect of the intervention [37].

The Skilled Care Initiative in Burkina Faso involved multiple activities to increase access to skilled birth care, including improving availability and quality of CEmOC by upgrading hospital capacity, equipment, and training in CEmOC at the district hospital (Table 2) $[38,39]$. At the end of the intervention period the PMR was 27.5/1000 in the intervention district compared with $33 / 1000$ in the control district (OR 0.75, 95\% CI 0.70-0.80) [38]. However, it is unclear how similar PMRs were in the intervention and control districts at the beginning of the intervention, and CEmOC was just one component of a complex intervention that also included community mobilization and education.

We identified historical reports from Malaysia [40] and Finland [1] that reported NMR trends coinciding with improvements in obstetric and neonatal care. In Malaysia, over three decades (1960-1990s), a national strategy to increase skilled birth attendance was implemented which included training professional village midwives (1970-80s), establishing links with district and referral hospitals, and a gradual shift to births in facilities with capacity for basic emergency obstetric care (1985-1990s). By 1995, institutional delivery had increased to $88 \%$ and the national NMR had declined from 75.5 in 1957 to 14.8 in 1991 [40]. In a Finnish university hospital, multiple obstetric and neonatal care improvements were instituted from 1968-1982 (including increased intrapartum monitoring, Caesarean section, corticosteroid therapy, amniotic fluid surfactant determination, and reduction in vaginal breech deliveries). Over the same time period, a $71 \%$ reduction in intrapartum-related neonatal mortality and a $61 \%$ reduction in all-cause perinatal mortality was observed. However, the effect of improved neonatal intensive care is likely to have played a major additional role in this mortality reduction.

In a tertiary care hospital in the UK, following an EmOC training course (cardiotocography interpretation; emergency drills for dystocia postpartum hemorrhage, eclampsia, breech delivery, and neonatal resuscitation) for obstetricians and midwives, a $50 \%$ reduction in hypoxic ischemic encephalopathy (95\% CI: 0.26-0.95) was observed [41]. However, baseline care was likely substantially more complex than in the 'average' lowincome country setting, and thus, this may underestimate the effect compared with no care. In addition the observed mortality reduction includes the effect of training in neonatal resuscitation, which is a separate intervention in LiST. Additional studies which provide supporting evidence of package effect are shown in Table 2, [42-45]. 
Table 2 Studies of the effect of Basic or Comprehensive Emergency Obstetric Care on perinatal-neonatal mortality or intrapartum-related outcomes

\begin{tabular}{|c|c|c|c|c|c|c|c|c|c|}
\hline Author & $\begin{array}{l}\text { Study } \\
\text { Years }\end{array}$ & Setting & $\begin{array}{l}\text { Study } \\
\text { Design }\end{array}$ & Intervention definition & $\begin{array}{l}\text { Concurrent } \\
\text { interventions }\end{array}$ & $\begin{array}{l}\text { Intervention } \\
\text { Coverage }\end{array}$ & $\begin{array}{l}\text { Total Births } \\
\text { A) Endline } \\
\text { B) Baseline }\end{array}$ & Outcomes & $\begin{array}{l}\text { Effect on } \\
\text { outcome } \\
\text { RR/OR } \\
(95 \% \mathrm{Cl}) \\
\end{array}$ \\
\hline $\begin{array}{l}\text { Ronsmans } \\
2010[37]\end{array}$ & $\begin{array}{l}1987- \\
2005\end{array}$ & $\begin{array}{l}\text { Matlab, } \\
\text { Bangladesh }\end{array}$ & $\begin{array}{l}\text { Observational } \\
\text { cross-sectional }\end{array}$ & $\begin{array}{l}\text { 1987-1996: skilled home birth care w/midwives } \\
\text { providing antenatal care, basic obstetric care } \\
\text { (labor monitoring), essential newborn care; } 1996 \\
\text { onwards facility based birth with BEmOC } \\
\text { (partograph, active management } 3^{\text {rd }} \text { stage, } \\
\text { antibiotics, management preeclampsia). Highest } \\
\text { level care received (BEmOC, CEmOC, vs no skilled } \\
\text { care) }\end{array}$ & $\begin{array}{l}\text { Antepartum care, } \\
\text { Essential newborn } \\
\text { care, Strengthening of } \\
\text { referral and transport } \\
\text { systems }\end{array}$ & $\begin{array}{l}\text { CEmOC } 0.5 \% \text { in } \\
1987 \text { to } 11.7 \% \text { in } \\
2005 \\
\text { BEmOC } 4.7 \% \text { in } \\
1987 \text { to } 40.9 \% \text { in } \\
2005\end{array}$ & $\begin{array}{l}\text { CEmOC } \\
3084 ; \\
\text { BEmOC } \\
\text { 9954; } \\
\text { No skilled } \\
\text { Care } 40177\end{array}$ & $\begin{array}{l}\text { 1) ENMR } \\
\text { 2) Stillbirth }\end{array}$ & $\begin{array}{l}\text { 1) CEmOC aOR } \\
\text { 2.69 (2.16-3.37) } \\
\text { BEmOC aOR } 1.47 \\
\text { (1.27-3.37) } \\
\text { 2) CEmOC aOR } \\
\text { 6.61(5.62-7.79) } \\
\text { BEmOC aOR } 1.51 \\
(1.31-1.73)\end{array}$ \\
\hline $\begin{array}{l}\text { Berglund } \\
2010[44]\end{array}$ & $\begin{array}{l}2003- \\
2004\end{array}$ & $\begin{array}{l}3 \text { Maternity } \\
\text { Hospitals; } \\
\text { Ukraine }\end{array}$ & $\begin{array}{l}\text { Observational } \\
\text { before-after }\end{array}$ & $\begin{array}{l}\text { Training all maternity staff (obstetricians, } \\
\text { neonataologists, midwives, anesthesiologists) in } 2 \\
\text { week WHO "Effective Perinatal Care" program, } \\
\text { including use of partogram, emergency obstetric } \\
\text { and neonatal care (resuscitation). }\end{array}$ & $\begin{array}{l}\text { Anesthesia; neonatal } \\
\text { resuscitation \& special } \\
\text { care, thermoregulation }\end{array}$ & $\begin{array}{l}\text { All maternity staff } \\
\text { in } 3 \text { hospitals }\end{array}$ & $\begin{array}{l}\text { A) } 1696 \\
\text { B) } 2439\end{array}$ & 1) ENMR & $\begin{array}{l}\text { No significant } \\
\text { effect }\end{array}$ \\
\hline $\begin{array}{l}\text { Hounton } \\
2008 \\
{[38,39,52]}\end{array}$ & $\begin{array}{l}2001- \\
2005\end{array}$ & $\begin{array}{l}\text { Rural } \\
\text { Ouargaye } \\
\text { and Diapaga } \\
\text { districts, } \\
\text { Burkina Faso }\end{array}$ & $\begin{array}{l}\text { Quasi- } \\
\text { experimental }\end{array}$ & $\begin{array}{l}\text { Upgrading of hospital, health centers in } \\
\text { intervention area. Mid-level, referral facilities: } \\
\text { emergency obstetric care training. First-level } \\
\text { centers: training in prevention of complications } \\
\text { and early detection -referral for emergencies. } \\
\text { Quality improvement infrastructure upgrading, } \\
\text { equipment and supplies }\end{array}$ & $\begin{array}{l}\text { National policies and } \\
\text { guidelines; } \\
\text { Mobilising/educating } \\
\text { communities to plan } \\
\text { for and use maternal } \\
\text { health services }\end{array}$ & $\begin{array}{l}\text { Training in } 1 \\
\text { district hospital } \\
\text { and } 13 / 19 \text { health } \\
\text { centers }\end{array}$ & $\begin{array}{l}18,658 \text { births } \\
\text { intervention } \\
\text { district } \\
2004-5 ; \\
21,788 \text { births } \\
\text { comparison } \\
\text { district } \\
2004-5\end{array}$ & 1) PMR & $\begin{array}{l}\text { 1) OR } 0.75(0.70- \\
0.80)\end{array}$ \\
\hline $\begin{array}{l}\text { Draycott } \\
2006 \text { [41] }\end{array}$ & $\begin{array}{l}1998- \\
2003\end{array}$ & $\begin{array}{l}\text { South Mead } \\
\text { Hospital, UK }\end{array}$ & Before-after & $\begin{array}{l}\text { EOC training course: CTG interpretation, course of } \\
\text { action, obstetric emergency drills (dystocia, PPH, } \\
\text { eclampsia, twins, breech, resuscitation) }\end{array}$ & & $\begin{array}{l}\text { Mandatory course } \\
\text { for all midwives }\end{array}$ & $\begin{array}{l}\text { A) } 11030 \\
\text { B) } 8430\end{array}$ & $\begin{array}{l}\text { 1) HIE } \\
\text { (MacLennan): }\end{array}$ & $\begin{array}{l}\text { 1) RR } 0.50(0.26- \\
0.95)\end{array}$ \\
\hline $\begin{array}{l}\text { Edmond } \\
\text { 2002[42] }\end{array}$ & $\begin{array}{l}1995- \\
1998\end{array}$ & $\begin{array}{l}\text { Natal, } \\
\text { Northeast } \\
\text { Brazil }\end{array}$ & $\begin{array}{l}\text { Observational } \\
\text { before-after }\end{array}$ & $\begin{array}{l}\text { Opening of primary maternity facilities at } \\
\text { polyclinic to serve low risk deliveries in the } \\
\text { community. Pre-booking of deliveries of high risk } \\
\text { pregnancies at Maternity hospital with CEmOC } \\
\text { capacity. }\end{array}$ & $\begin{array}{l}\text { ANC, community } \\
\text { health agents training } \\
\text { in community health } \\
\text { clinics }\end{array}$ & $\begin{array}{l}\text { Deliveries at } \\
\text { maternity clinics } \\
\text { increased from } 0 \% \\
\text { to } 51 \%\end{array}$ & $\begin{array}{l}\text { A) } 536 \\
\text { B) } 679\end{array}$ & $\begin{array}{l}\text { 1) ENMR } \\
\text { 2) Stillbirth } \\
\text { 3) PMR }\end{array}$ & $\begin{array}{l}\text { 1) RR } 0.12 \text { (0.04- } \\
0.40) \\
\text { 2) } R R 0.66 \text { (0.47- } \\
0.94) \\
\text { 3) RR } 0.52 \text { (0.37- } \\
0.73)\end{array}$ \\
\hline $\begin{array}{l}\text { McCord } \\
2001[43]\end{array}$ & $\begin{array}{l}1996- \\
1999\end{array}$ & $\begin{array}{l}\text { Rural } \\
\text { Maharashtra, } \\
\text { India }\end{array}$ & $\begin{array}{l}\text { Cross- } \\
\text { sectional }\end{array}$ & $\begin{array}{l}\text { Comparison of perinatal mortality among births } \\
\text { occurring at home vs. in hospital, some with } \\
\text { CEmOC }\end{array}$ & & $\begin{array}{l}85 \% \text { home births, } \\
15 \% \text { in hospital. }\end{array}$ & $\begin{array}{l}\text { Home: } 2436 \\
\text { Hospital: } 425\end{array}$ & 1) PMR & $\begin{array}{l}\text { PMR } 27.1 \text { (home } \\
\text { births) vs } 87 \\
\text { (hospital } \\
\text { deliveries) }\end{array}$ \\
\hline $\begin{array}{l}\text { Koblinsky } \\
\text { 1999[40] }\end{array}$ & $\begin{array}{l}1957- \\
1990 s\end{array}$ & Malaysia & $\begin{array}{l}\text { Historical- } \\
\text { ecological }\end{array}$ & $\begin{array}{l}1960 \text { s Training of professional village midwives, } \\
\text { linking to regional clinics, referral to district } \\
\text { hospitals; 1980's shift to facility births with BEmOC }\end{array}$ & $\begin{array}{l}3 \text { decades of perinatal } \\
\text { care and obstetric care } \\
\text { upgrading }\end{array}$ & $\begin{array}{l}95 \% \text { of births by } \\
\text { midwives (1996); } \\
80 \% \text { of risk } \\
\text { deliveries in } \\
\text { hospital (1998) }\end{array}$ & NS & 1) NMR & $\begin{array}{l}\text { NMR from } 75.5 \\
\text { (1957) to } 14.8 \\
\text { (1991) }\end{array}$ \\
\hline $\begin{array}{l}\text { Korhonen } \\
\text { 1994[45] }\end{array}$ & $\begin{array}{l}1986- \\
1991\end{array}$ & $\begin{array}{l}\text { Helsinki, } \\
\text { Finland }\end{array}$ & $\begin{array}{l}\text { Cross- } \\
\text { sectional }\end{array}$ & $\begin{array}{l}\text { Emergency Caesarean Team in Hospital vs. On call } \\
\text { (out of hospital, } 10 \text { minute average delay) }\end{array}$ & & NS & $\begin{array}{l}60 \text { in } \\
\text { hospital; } \\
41 \text { on call }\end{array}$ & $\begin{array}{l}\text { 1) Fetal } \\
\text { Death; } \\
\text { 2) HIE }\end{array}$ & $\begin{array}{l}3 \text { in utero fetal } \\
\text { deaths and } 1 \mathrm{HIE} \\
\text { in control (on-call) } \\
\text { group vs } 0 \\
\text { hospital }\end{array}$ \\
\hline $\begin{array}{l}\text { Piekkala } \\
1985[1]\end{array}$ & $\begin{array}{l}1968- \\
1982\end{array}$ & $\begin{array}{l}\text { University } \\
\text { Hospital, } \\
\text { Turku } \\
\text { Finland }\end{array}$ & Historical & $\begin{array}{l}15 \text { year improvement in obstetric management: } \\
\text { Cesearean rate increase from 4-12\%; vaginal } \\
\text { breech delivery from } 4 \text { to 1\%; implementation of } \\
\text { antepartum CTG (monitoring increase from } 0 \text { to } \\
90 \% \text { ) }\end{array}$ & $\begin{array}{l}\text { Corticosteroids, } \\
\text { Neonatal intensive } \\
\text { care, respiratory } \\
\text { therapy, fluid- } \\
\text { nutritional therapy }\end{array}$ & $\begin{array}{l}\text { Referral hospital } \\
\text { for } 10 \% \text { of } \\
\text { population }\end{array}$ & $\begin{array}{l}\text { A) } 5,410 \\
\text { B) } 5,996\end{array}$ & $\begin{array}{l}\text { 1) PMR } \\
\text { 2) } \\
\text { Intrapartum } \\
\text { mortality }\end{array}$ & $\begin{array}{l}\text { 1) RR } 0.39 \\
\text { 2) RR } 0.29\end{array}$ \\
\hline
\end{tabular}


Our ecological analysis of the association between NE incidence and the proportion of institutional births is shown in Figure 4. The modelled incidence of neonatal encephalopathy when $10 \%$ of deliveries take place in health facilities was 18.6/1000 live births. Given a neonatal case fatality ratio of $25 \%$ using the median neonatal case fatality in high mortality level settings $(\mathrm{NMR}>15)$ from the literature review [33], the neonatal encephalopathy mortality rate would be around 4.7/1000 live births. When $90 \%$ of births take place in a facility, the modelled incidence of neonatal encephalopathy is $4.7 / 1000$ live births (figure 4). Given a case fatality ratio of $15 \%$ [33], this results in a neonatal encephalopathy mortality rate of $0.7 / 1000$ live births, which is around the reported rate for associated obstetric factors in the UK[46]. Thus, comparing 10\% facility birth and $90 \%$ facility births, there is approximately a 75\% reduction in the incidence of neonatal encephalopathy and an $85 \%$ reduction in neonatal encephalopathy-related mortality. This reduction, however, assumes that facility birth equates to prompt access to emergency obstetric care, and includes the effect of neonatal resuscitation and ongoing facility-based neonatal care, both of which may not be available in many facilities in low-resource settings. Hence this effect size (85\%) may be expected to be above the upper limit of the effect of comprehensive obstetric care, not including resuscitation or ongoing neonatal care.

\section{Skilled childbirth care}

For a delivery attendant alone, provider training may avert hypoxic brain injury by primary prevention via early recognition and referral for childbirth complications, or by secondary prevention, via managing the nonbreathing baby with essential newborn care and neonatal resuscitation. The focus of this current review is on

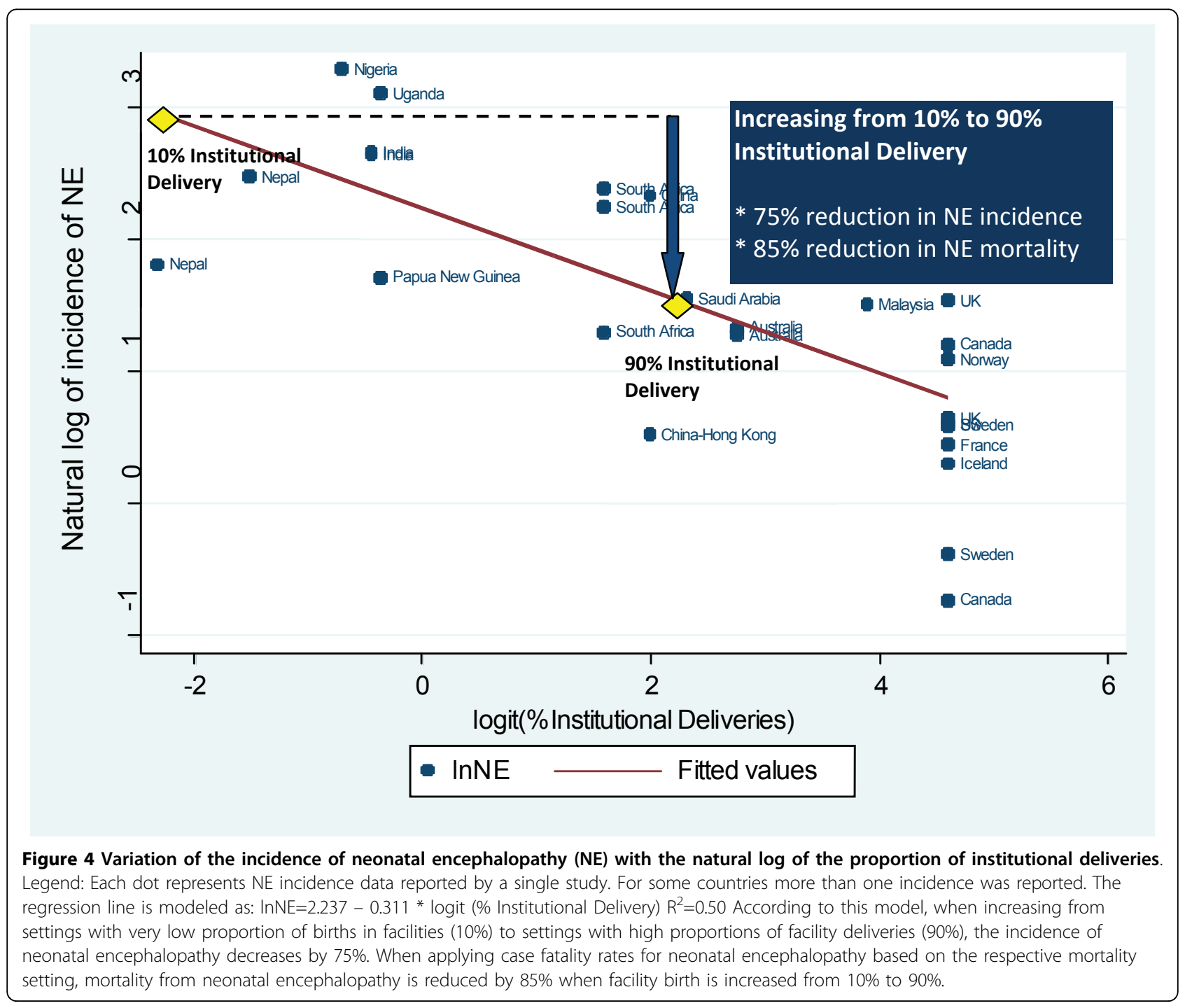


primary prevention, as neonatal resuscitation and thermal care are reviewed separately for LiST $[24,47]$. The evidence with respect to home-based skilled childbirth care has been reviewed in detail elsewhere [35]. We identified 10 studies reporting the impact of community-based skilled birth attendants on intrapartumrelated perinatal or neonatal mortality (Tables 3 and 4): 2 quasi-experimental studies, 4 before-after studies, and 4 observational historical studies. Nine studies were from low- or middle-income settings.

Four studies met our inclusion criteria and had trained community midwives [48-51] or village doctors [48] in intrapartum monitoring and management, with appropriate links to the health system, including referral and or transport to BEmOC or CEmOC facilities. Additional file 1 and Table 5 shows the GRADE table of included studies and their limitations. Only one study reported the effect of training community midwives on intrapartum-related neonatal mortality (RR 0.78, 95\% CI 0.64-0.95) [50].

We undertook meta-analysis for three outcomes (figures 5, 6, 7). The before-after data was used instead of the quasi-experimental comparisons because in one study the control group had different baseline characteristics [52], and in the other, there was contamination of the intervention in the comparison areas [50]. Two studies $[49,50]$ reported the effect on all-cause neonatal mortality (pooled effect size RR 0.82, 95\% CI 0.75-0.90). Three studies [48-50] reported the effects on early neonatal mortality (pooled effect size RR $0.87,95 \%$ CI 0.79 0.97 ), which is more reflective of intrapartum-related mortality than all-cause NMR given that $\sim 90 \%$ of "asphyxia" deaths occur in the first week of life [53,54]. Four studies reported the effect on perinatal mortality; the pooled effect was RR 0.88 (95\% CI 0.83-0.95) [48-51]. While the data appear to indicate a consistent small protective effect of skilled childbirth care and all of the studies were conducted in low-income countries, the overall quality of the evidence is low by GRADE criteria [17].

Six studies of community midwives were excluded from these meta-analyses. Of these, four historical studies were excluded due to the very low data quality [40,55-57] . We also excluded a study from PATH Indonesia [58], which was a before-after design that did not accurately determine the denominator of live births and was primarily focused on training for neonatal resuscitation. The Matthews study [59] was excluded as the midwives and EmOC skills training were facility-based, while the community based component involved TBA training only.

\section{Traditional birth attendant training}

The intervention reviewed is the impact of training TBAs in childbirth care, or primary prevention via early recognition and referral for obstetric emergencies, and excludes neonatal resuscitation, which is reviewed separately. The evidence for TBA training has been reviewed in detail elsewhere [35]. We present here a summary of the main findings. We identified one review [60], later adapted as a Cochrane [61], and 9 studies of TBAs with neonatal mortality outcomes (figure 2). Of the 9 studies, 5 studies were excluded as they focused primarily on neonatal resuscitation training versus primary prevention leaving 1 cluster RCT, 2 before-after studies and 1 cross-sectional study of interest (table 6).

Sibley and Sipe [60] conducted a meta-analysis in 2004 of 17 studies ( $\mathrm{n}=15286$ in treatment vs 12786 in control) and reported a $6 \%$ reduction in all-cause perinatal or neonatal deaths in the areas served by trained TBAs. TBA training was heterogeneous between studies, however, and included both primary and secondary prevention measures (neonatal resuscitation). In their pooled analysis of 3 studies $(n=6217$ neonates in the treatment group vs 5170 controls), TBA training was associated with an $11 \%$ reduction in "birth asphyxia" mortality, though this effect estimate also captures the effect of TBA training in neonatal resuscitation as it included 3 sites with TBA resuscitation (the SEARCH trial during the TBA training phase [62], Chandigarh, India [63], and Ethiopia [64]).

In a Cochrane review conducted by Sibley et al [61], two studies with mortality outcomes met quality inclusion criteria. A large, cluster-randomized, controlled trial (cRCT) was conducted in Sindh, Pakistan, where TBAs in intervention areas were trained to encourage care-seeking, recognize obstetric emergencies, refer for EmOC, use clean delivery kits, and promote essential newborn care [65]. Furthermore, these TBAs were integrated into the health system by improving linkages with Lady Health Workers and community clinics. Pregnant women attended by trained TBAs were more likely to be diagnosed with obstructed labor $(\mathrm{RR}=1.26,95 \% \mathrm{CI}$ 1.03-1.54) and referred for EmOC (RR 1.50, 95\% CI $1.19-1.90)$. PMR was reduced by $30 \%$ in intervention clusters (OR 0.70, 95\% CI 0.60-0.80), stillbirth rate was reduced by $31 \%$ (OR $0.69,95 \%$ CI $0.57-0.83$ ) and NMR by $29 \%$ (OR $0.71,95 \%$ CI $0.62-0.83$ ). Intrapartum-related mortality was not reported; however, the concurrent reduction in both stillbirths and neonatal deaths suggests the primary prevention of intrapartum injury. The second study included in the Cochrane review was a before-after assessment of hospital-based TBA training in Guatemala [66]. Following training, there was a 53\% reduction in perinatal deaths among those women referred to the hospital for delivery (16/72 pre-training vs. 24/203 post-training). However, given that the outcomes of community-based births are unknown, it was not possible to determine the impact at the population 
Table 3 Studies of the impact of community skilled birth attendants on perinatal-neonatal mortality

\begin{tabular}{|c|c|c|c|c|c|c|c|c|c|c|}
\hline Author & $\begin{array}{l}\text { Study } \\
\text { Years }\end{array}$ & Country & Setting & Study Design & Primary Intervention & $\begin{array}{l}\text { Concurrent } \\
\text { Interventions }\end{array}$ & $\begin{array}{l}\text { Intervention } \\
\text { Coverage }\end{array}$ & $\begin{array}{l}\text { Total N } \\
\text { A) Intervention } \\
\text { B) Comparison }\end{array}$ & $\begin{array}{l}\text { Outcomes } \\
\text { Measured }\end{array}$ & $\begin{array}{l}\text { Effect on } \\
\text { outcome } \\
\text { (95\% Cl) }\end{array}$ \\
\hline $\begin{array}{l}\text { Ronsmans } \\
2008[50]\end{array}$ & $\begin{array}{l}1975- \\
1999\end{array}$ & $\begin{array}{l}\text { Matlab, } \\
\text { Bangladesh }\end{array}$ & $\begin{array}{l}\text { Rural, 1987- } \\
1996 \text { SBA at } \\
\text { home }\end{array}$ & $\begin{array}{l}\text { Quasi- } \\
\text { experimental } \\
\text { (tuse of } \\
\text { before-after } \\
\text { data in pooled } \\
\text { anlaysis) }\end{array}$ & $\begin{array}{l}\text { Posting of midwives in villages to increase } \\
\text { skilled home birth (antenatal, basic obstetric, } \\
\text { care including labor monitoring, essential } \\
\text { newborn care) until 1996. After 1996, facility } \\
\text { based strategy with upgrading of health } \\
\text { centers in basic obstetric care (partograph } \\
\text { use, active management } 3^{\text {rd }} \text { stage, antibiotics, } \\
\text { magnesium) }\end{array}$ & $\begin{array}{l}\text { Strengthening referral } \\
\text { systems, Transport to } \\
\text { BEMOC or CEmOC }\end{array}$ & $\begin{array}{l}25 \% \text { of births } \\
\text { attended by } \\
\text { SBA during } \\
\text { home birth } \\
\text { period }\end{array}$ & $\begin{array}{l}\text { A) } 19085 \\
\text { (ICDDR,B 1989- } \\
\text { 1995) } \\
\text { B) 22821 } \\
\text { (ICDDR,B 1982- } \\
\text { 1988) }\end{array}$ & $\begin{array}{l}\text { 1) IPR-NMR } \\
\text { 2) NMR }+ \\
\text { 3) ENMR† } \\
\text { 4) PMR† }\end{array}$ & $\begin{array}{l}\text { 1) } 0.78 \\
\text { (NS) } \\
\text { 2) } 0.83 \\
(0.76-0.91) \\
\text { 3) } 0.89 \\
\text { (0.80-0.97) } \\
\text { 4) } 0.92 \\
\text { (0.84-0.98) }\end{array}$ \\
\hline $\begin{array}{l}\text { Yan } 1989 \\
{[48]}\end{array}$ & $\begin{array}{l}1983- \\
1986\end{array}$ & $\begin{array}{l}\text { Shunyi, } \\
\text { China }\end{array}$ & $\begin{array}{l}\text { Rural } \\
\text { Shunyi } \\
\text { County, } 7 \\
\text { of } 29 \\
\text { townships }\end{array}$ & Before-after & $\begin{array}{l}\text { Village doctors-midwives identify risk and } \\
\text { either manage (external cephalic version, } \\
\text { blood pressure monitoring) or refer mothers } \\
\text { to county hospital }\end{array}$ & $\begin{array}{l}\text { Improvement of } \\
\text { neonatal ward in } \\
\text { county hospital }\end{array}$ & $\begin{array}{l}96 \% \text { of } \\
\text { pregnant } \\
\text { women seen } \\
\text { by village } \\
\text { doctor- } \\
\text { midwife }\end{array}$ & $\begin{array}{l}\text { A) } 2335 \\
\text { B) } 2212\end{array}$ & $\begin{array}{l}\text { 1) } P M R \\
\text { 2) EMR } \\
\text { 3) IP-PMR }\end{array}$ & $\begin{array}{l}\text { 1) } 0.66 \\
(0.44-0.98) \\
\text { 2) } 0.77 \\
(0.43-1.36) \\
\text { 3) } 0.73(*)\end{array}$ \\
\hline $\begin{array}{l}\text { Ibrahim } \\
\text { 1992[49] }\end{array}$ & $\begin{array}{l}1985- \\
1988\end{array}$ & $\begin{array}{l}\text { Khartoum, } \\
\text { Sudan }\end{array}$ & $\begin{array}{l}\text { Rural, 91\% } \\
\text { home } \\
\text { delivery }\end{array}$ & Before-after & $\begin{array}{l}\text { Training and upgrading of skills of village } \\
\text { midwives (antenatal care, monitoring in labor) }\end{array}$ & $\begin{array}{l}\text { Data collection } \\
\text { maternal-perinatal } \\
\text { outcomes, referral } \\
\text { system to hospital }\end{array}$ & $\begin{array}{l}91 \% \text { of births } \\
\text { delivered by } \\
\text { village } \\
\text { midwives }\end{array}$ & $\begin{array}{l}\text { A) } 2298 \\
\text { B) } 3977\end{array}$ & $\begin{array}{l}\text { 1) NMR } \\
\text { 2) ENMR } \\
\text { 3) SBR }\end{array}$ & $\begin{array}{l}\text { 1) } 0.68 \\
(0.48-0.97) \\
\text { 2) } 0.78 \\
(0.61-1.01) \\
\text { 3) } 0.85 \\
(0.60-1.19)\end{array}$ \\
\hline $\begin{array}{l}\text { Alisjahbana } \\
\text { 1995[51] }\end{array}$ & $\begin{array}{l}1992- \\
1993\end{array}$ & $\begin{array}{l}\text { West Java, } \\
\text { Indonesia }\end{array}$ & $\begin{array}{l}\text { Rural } \\
\text { villages, } \\
\text { West Java; } \\
\text { Tanjungsari } \\
\text { district }\end{array}$ & $\begin{array}{l}\text { Quasi- } \\
\text { experimental } \\
\text { (use of before- } \\
\text { after data in } \\
\text { pooled } \\
\text { analysis) }\end{array}$ & $\begin{array}{l}\text { Training physicians and village midwives on } \\
\text { danger signs, case management in } \\
\text { pregnancy, labor, delivery, postpartum; } \\
\text { development of birthing homes }\end{array}$ & $\begin{array}{l}\text { Training TBAs in } \\
\text { pregnancy detection, } \\
\text { complications and } \\
\text { referral; } \\
\text { communications and } \\
\text { transportation }\end{array}$ & $\begin{array}{l}92 \% \text { of births } \\
\text { with } \\
\text { professional } \\
\text { provider }\end{array}$ & $\begin{array}{l}\text { A) } 1176 \\
\text { B) } 1099\end{array}$ & 1) $P M R$ & $\begin{array}{l}0.75(0.51- \\
1.10)\end{array}$ \\
\hline
\end{tabular}


Table 4 Studies of the impact of community skilled birth attendants on perinatal-neonatal mortality, excluded from meta-analysis

\begin{tabular}{|c|c|c|c|c|c|c|c|c|c|c|}
\hline Author & $\begin{array}{l}\text { Study } \\
\text { Years }\end{array}$ & Country & Setting & $\begin{array}{l}\text { Study } \\
\text { Design }\end{array}$ & Primary Intervention & $\begin{array}{l}\text { Concurrent } \\
\text { Interventions }\end{array}$ & Intervention Coverage & $\begin{array}{l}\text { Total N } \\
\text { A) Intervention } \\
\text { B) Comparison }\end{array}$ & $\begin{array}{l}\text { Outcome } \\
\text { Measured }\end{array}$ & $\begin{array}{l}\text { Effect on } \\
\text { outcome } \\
\text { RR/OR } \\
(95 \% \mathrm{Cl})\end{array}$ \\
\hline $\begin{array}{l}\text { Matthews } \\
\text { 2004[59] }\end{array}$ & $\begin{array}{l}1999- \\
2002\end{array}$ & Ghana & $\begin{array}{l}\text { Rural } \\
\text { Brong } \\
\text { Ahafo } \\
\text { district }\end{array}$ & $\begin{array}{l}\text { Before- } \\
\text { after }\end{array}$ & $\begin{array}{l}\text { Training midwives in health facilities } \\
\text { on use of partograph and emergency } \\
\text { obstetric skills }\end{array}$ & $\begin{array}{l}\text { TBA Training in } \\
\text { danger signs, } \\
\text { Emergency } \\
\text { obstetric } \\
\text { transport service }\end{array}$ & NS & $\begin{array}{l}\text { A) } 768 \\
\text { B) } 575\end{array}$ & 1) $P M R$ & NS \\
\hline $\begin{array}{l}\text { Andersson } \\
2000[55]\end{array}$ & $\begin{array}{l}1831- \\
1899\end{array}$ & Sweden & $\begin{array}{l}18 \\
\text { Parishes } \\
\text { Northern } \\
\text { Sweden }\end{array}$ & Historical & $\begin{array}{l}1829 \text { Training of midwives in use of } \\
\text { forceps, "sharp hooks and } \\
\text { perforators" }\end{array}$ & $\begin{array}{l}1881 \text { antiseptic } \\
\text { techniques }\end{array}$ & $\begin{array}{l}73 \% \text { of home deliveries attended by } \\
\text { midwives at endline ( } 43 \% \text { baseline) }\end{array}$ & NS & 1) $P M R$ & $\begin{array}{l}\text { 1) } 0.71(0.62- \\
0.82)\end{array}$ \\
\hline $\begin{array}{l}\text { Hatt } 2009 \\
{[56]}\end{array}$ & $\begin{array}{l}1986- \\
2002\end{array}$ & Indonesia & $\begin{array}{l}\text { National } \\
\text { DHS Data }\end{array}$ & Historical & $\begin{array}{l}\text { Village midwife training program } \\
\text { started in } 1989 \text {, by } 199550,000 \\
\text { trained. In } 1996 \text { competency based } \\
\text { training, neonatal resuscitation }\end{array}$ & $\begin{array}{l}2 \text { decades of } \\
\text { national } \\
\text { perinatal care } \\
\text { and obstetric } \\
\text { care upgrading }\end{array}$ & $\begin{array}{l}\text { Proportion of deliveries attended by } \\
\text { midwives increased from 12\% (1986) } \\
\text { to 30\% (2002) }\end{array}$ & NS & $\begin{array}{l}\text { 1) ENMR } \\
\text { 2) First } \\
\text { day } \\
\text { mortality }\end{array}$ & $\begin{array}{l}\text { 1) } 0.97 \\
(0.95-0.99) \\
\text { per year } \\
\text { reduction } \\
\text { 2) } 0.98(0.95-\text { - } \\
\text { 1.02) per } \\
\text { year } \\
\text { reduction }\end{array}$ \\
\hline $\begin{array}{l}\text { Koblinsky } \\
\text { 1999[40] }\end{array}$ & $\begin{array}{l}1957- \\
1990 s\end{array}$ & Malaysia & $\begin{array}{l}\text { National } \\
\text { NMR }\end{array}$ & $\begin{array}{l}\text { Historical- } \\
\text { ecological }\end{array}$ & $\begin{array}{l}1960 \text { s Training of professional village } \\
\text { midwives, linking to regional clinics, } \\
\text { referral to district hospitals; 1980's } \\
\text { shift to facility births }\end{array}$ & $\begin{array}{l}3 \text { decades of } \\
\text { perinatal care } \\
\text { and obstetric } \\
\text { care upgrading }\end{array}$ & $\begin{array}{l}\text { By } 1986,95 \% \text { of home births by } \\
\text { midwives; by } 1995,88 \% \text { institutional } \\
\text { delivery; } 90 \% \text { of women with high } \\
\text { risk, } 80 \% \text { moderate risk delivering in } \\
\text { hospitals }\end{array}$ & NS & 1) NMR & $\begin{array}{l}\text { NMR from } \\
75.5(1957) \\
\text { to } 14.8 \\
(1991)\end{array}$ \\
\hline $\begin{array}{l}\text { PATH } 2006 \\
\text { [58] }\end{array}$ & $\begin{array}{l}2003- \\
2004\end{array}$ & $\begin{array}{l}\text { Cirebon, } \\
\text { Indonesia }\end{array}$ & $\begin{array}{l}\text { Rural } \\
\text { Cirebon } \\
\text { district, } \\
\text { west Java, } \\
\text { pop } 2 \text { mill }\end{array}$ & $\begin{array}{l}\text { Before- } \\
\text { After }\end{array}$ & $\begin{array}{l}\text { Training mid-wives in management } \\
\text { of labor, birth asphyxia, tube-mask } \\
\text { resuscitation, refresher training/ } \\
\text { supervision }\end{array}$ & & $\begin{array}{l}60 \% \text { of asphyxia cases managed by } \\
\text { midwives. Uncertain coverage }\end{array}$ & Est 44000 & $\begin{array}{l}\text { 1) IPR- } \\
\text { NMR } \\
\text { 2) NMR } \\
\text { 3) SBR }\end{array}$ & $\begin{array}{l}\text { 1) } 0.39 \\
\text { (0.31- } 0.48) \\
\text { 2) } 0.60 \\
(0.53-0.68) \\
\text { 3) } 0.39 \\
(0.31-0.48)\end{array}$ \\
\hline $\begin{array}{l}\text { Shankar } \\
\text { 2008[57] }\end{array}$ & $\begin{array}{l}1989- \\
2003\end{array}$ & Indonesia & $\begin{array}{l}\text { National } \\
\text { NMR }\end{array}$ & Historical & $\begin{array}{l}\text { Village midwife training program } \\
\text { started in } 1989 \text {, by } 199550,000 \\
\text { trained. In } 1996 \text { competency based } \\
\text { training program including neonatal } \\
\text { resuscitation }\end{array}$ & $\begin{array}{l}2 \text { decades of } \\
\text { national } \\
\text { perinatal care } \\
\text { and obstetric } \\
\text { care upgrading }\end{array}$ & $\begin{array}{l}\text { In rural areas skilled attendance } \\
\text { increased from } 22 \% \text { to } 55 \%\end{array}$ & NS & 1) NMR & $\begin{array}{l}\text { NMR } \\
\text { decreased } \\
\text { from } 32 \text { to } \\
20 / 1000 \\
\text { over } 14 \\
\text { years }\end{array}$ \\
\hline
\end{tabular}


Table 5 GRADE summary table for the impact of community skilled birth attendants on perinatal-neonatal outcomes

\begin{tabular}{|c|c|c|c|c|c|c|c|c|c|c|}
\hline \multirow[b]{3}{*}{$\begin{array}{l}\text { No of } \\
\text { studies }\end{array}$} & \multicolumn{3}{|l|}{ Study Quality } & \multirow{2}{*}{\multicolumn{2}{|c|}{ Directness }} & \multicolumn{5}{|c|}{ Summary of Findings } \\
\hline & \multirow[b]{2}{*}{ Design } & \multirow[b]{2}{*}{ Limitations } & \multirow[b]{2}{*}{ Consistency } & & & \multicolumn{2}{|l|}{ Endline } & \multicolumn{2}{|c|}{ Baseline } & \multirow[b]{2}{*}{$\begin{array}{l}\text { Relative } \\
\text { Risk } \\
(95 \% \mathrm{Cl})\end{array}$} \\
\hline & & & & $\begin{array}{l}\text { Generalizability } \\
\text { to Population } \\
\text { of Interest }\end{array}$ & $\begin{array}{l}\text { Generalizability } \\
\text { to intervention } \\
\text { of interest }\end{array}$ & Events & Births & Events & Births & \\
\hline \multicolumn{11}{|c|}{ Neonatal Mortality(Intrapartum-related): Low outcome specific quality } \\
\hline $1[50]$ & $\begin{array}{l}\text { Quasi- } \\
\text { experimental }\end{array}$ & $\begin{array}{l}\text { Several interventions } \\
\text { simultaneously and } \\
\text { changes also in } \\
\text { comparison villages }\end{array}$ & & $\begin{array}{l}\text { Community- } \\
\text { setting LIC-MIC, } \\
\text { South Asia }\end{array}$ & Yes & NS & 19,085 & NS & 22,413 & $\begin{array}{l}0.78 \\
(0.64- \\
0.95)\end{array}$ \\
\hline \multicolumn{11}{|c|}{ Neonatal Mortality(All Cause): Low outcome specific quality } \\
\hline $\begin{array}{l}2 \\
{[49,50]}\end{array}$ & $\begin{array}{l}\text { Observational, } \\
\text { before-after }\end{array}$ & $\begin{array}{l}\text { Low quality, before- } \\
\text { after comparisons }\end{array}$ & $\begin{array}{l}\text { No evidence } \\
\text { of } \\
\text { heterogeneity } \\
(p=0.28)\end{array}$ & $\begin{array}{l}\text { Community- } \\
\text { setting LIC-MIC }\end{array}$ & Yes & 794 & 21383 & 1186 & 26798 & $\begin{array}{l}0.82 \\
(0.75- \\
0.90)^{a}\end{array}$ \\
\hline \multicolumn{11}{|c|}{ Early Neonatal Mortality(All Cause): Low outcome specific quality } \\
\hline $\begin{array}{l}3 \\
{[48-50]}\end{array}$ & $\begin{array}{l}\text { Observational, } \\
\text { before-after }\end{array}$ & $\begin{array}{l}\text { Low quality, before- } \\
\text { after comparisons }\end{array}$ & $\begin{array}{l}\text { No evidence } \\
\text { of } \\
\text { heterogeneity } \\
(p=0.50)\end{array}$ & $\begin{array}{l}\text { Community- } \\
\text { setting LIC-MIC }\end{array}$ & Yes & 597 & 23718 & 837 & 29010 & $\begin{array}{l}0.87 \\
(0.79- \\
0.97)^{a}\end{array}$ \\
\hline \multicolumn{11}{|c|}{ Perinatal Mortality(All Cause): Low outcome specific quality } \\
\hline $\begin{array}{l}4 \\
{[48-51]}\end{array}$ & $\begin{array}{l}\text { Observational, } \\
\text { before-after }\end{array}$ & $\begin{array}{l}\text { Low quality, before- } \\
\text { after comparisons }\end{array}$ & $\begin{array}{l}\text { Evidence of } \\
\text { heterogeneity } \\
(p=0.12)\end{array}$ & $\begin{array}{l}\text { Community- } \\
\text { setting LIC-MIC }\end{array}$ & Yes & 670 & 21981 & 909 & 27621 & $\begin{array}{l}0.88 \\
(0.83-.95) \\
b\end{array}$ \\
\hline
\end{tabular}

NS $=$ Not Stated

a) MH pooled RR; b) D \& L pooled RR random effect meta-analysis.

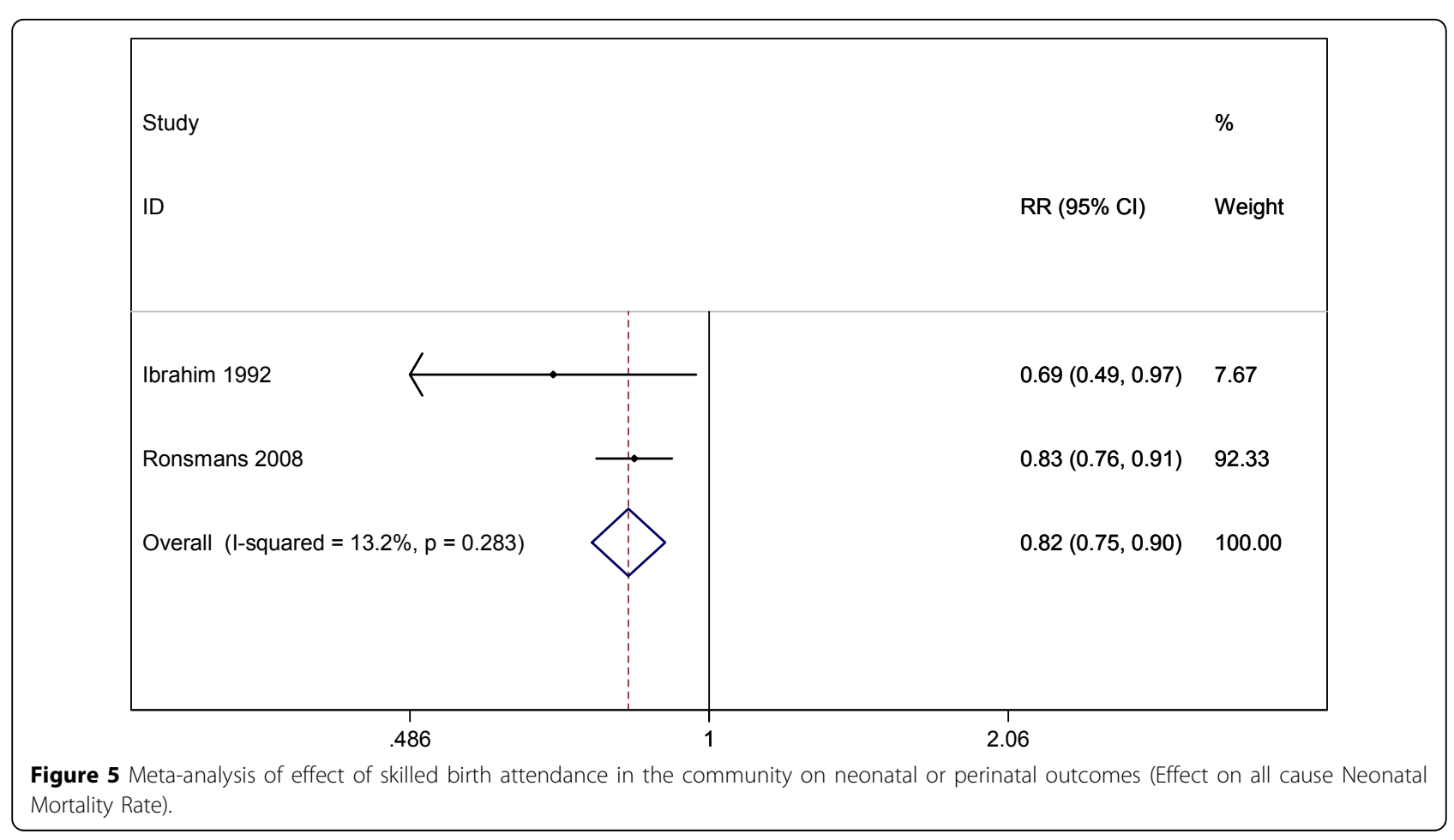



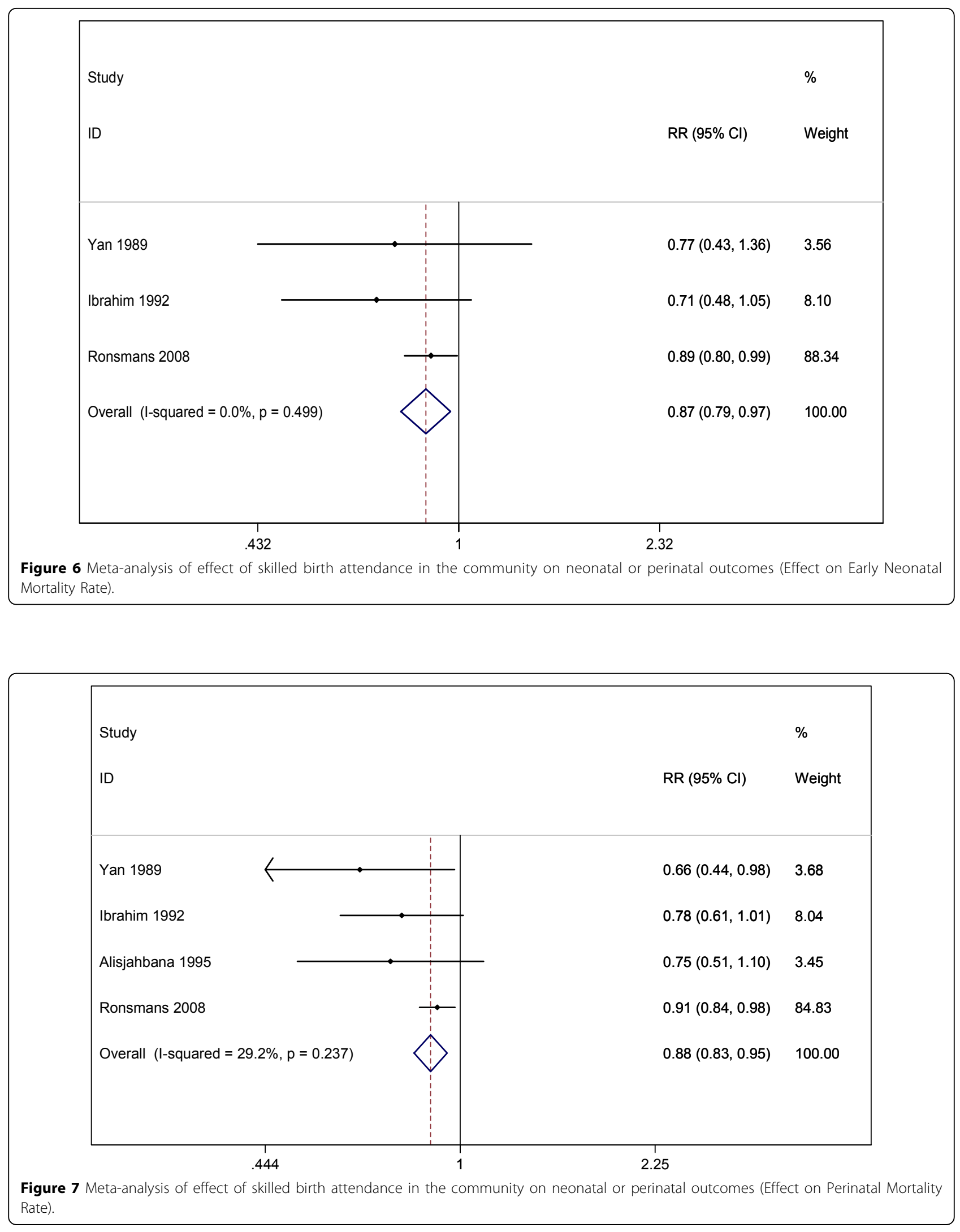
Table 6 Individual studies of the effect of traditional birth attendant training in intrapartum care on perinatal-neonatal mortality

\begin{tabular}{|c|c|c|c|c|c|c|c|c|c|}
\hline Author & $\begin{array}{l}\text { Study } \\
\text { years }\end{array}$ & Setting & $\begin{array}{l}\text { Study } \\
\text { Design }\end{array}$ & Intervention definition & Concurrent interventions & $\begin{array}{l}\text { Intervention } \\
\text { Coverage }\end{array}$ & $\begin{array}{l}\text { Total } N \\
\text { ( } A=\text { =intervention/ } \\
\text { endline; } \\
B=\text { control/ } \\
\text { baseline) }\end{array}$ & Outcomes & $\begin{array}{l}\text { Effect on } \\
\text { outcome } \\
\text { RR/OR } \\
(95 \% \mathrm{Cl})\end{array}$ \\
\hline O'Rourke[66] & 1991 & $\begin{array}{l}\text { Rural } \\
\text { Guatemala }\end{array}$ & $\begin{array}{l}\text { Before-after } \\
\text { comparison }\end{array}$ & $\begin{array}{l}\text { 3-month hospital-based training program for } \\
\text { TBAs - identification of obstetric emergency } \\
\text { and referral; encouragement to attend } \\
\text { hospital deliveries; strengthening relationships } \\
\text { between TBAs and hospital staff }\end{array}$ & & $\begin{array}{l}\text { Studied only } \\
\text { those } \\
\text { patients who } \\
\text { were } \\
\text { sucessfully } \\
\text { referred }\end{array}$ & $\begin{array}{l}\text { A) } 465 \text {; } \\
\text { B) } 39\end{array}$ & $\begin{array}{l}\text { 1) PMR } \\
\text { among } \\
\text { referred } \\
\text { infants* }\end{array}$ & RR 0.73 \\
\hline $\begin{array}{l}\text { Greenwood } \\
\text { et al. [86] }\end{array}$ & 1983 & Rural Gambia & $\begin{array}{l}\text { Before-after } \\
\text { comparison }\end{array}$ & $\begin{array}{l}\text { TBA training in intervention villages within a } \\
\text { comprehensive primary care program; } 10 \\
\text { week training courseantenatal-postnatal care, } \\
\text { referral signs; distribute clean birth kit and } \\
\text { malaria prophylaxis }\end{array}$ & $\begin{array}{l}\text { Introduction of comprehensive } \\
\text { primary health care program, } \\
\text { transport improvements }\end{array}$ & $65 \%$ & $\begin{array}{l}\text { A) } 1159 \\
\text { B) } 659\end{array}$ & $\begin{array}{l}\text { 1) NMR; } \\
\text { 2) PMR }\end{array}$ & $\begin{array}{l}\text { 1) RR } 0.66 \text {; } \\
\text { 2) RR } 0.92\end{array}$ \\
\hline $\begin{array}{l}\text { Janowitz } \\
\text { et al. [74] }\end{array}$ & $\begin{array}{l}1984- \\
85\end{array}$ & $\begin{array}{l}\text { Rural NE } \\
\text { Brazil }\end{array}$ & $\begin{array}{l}\text { Cross- } \\
\text { sectional }\end{array}$ & $\begin{array}{l}\text { TBA training especially in recognition of } \\
\text { childbirth complications and referral. Non- } \\
\text { randomized comparison of trained TBAs with } \\
\text { high case load ( }>29 \text { births per year) versus } \\
\text { unattended home births }\end{array}$ & $\begin{array}{l}\text { Establishment of "mini- } \\
\text { maternities" with telephones for } \\
\text { TBA births. }\end{array}$ & $55 \%$ & $\begin{array}{l}\text { A) } 906 \text {; } \\
\text { B) } 118\end{array}$ & 1) NMR & RR 0.60 \\
\hline $\begin{array}{l}\text { Jokhio et al. } \\
\text { [65] }\end{array}$ & 1998 & $\begin{array}{l}\text { Rural } \\
\text { Pakistan, } \\
\text { Larkana, }\end{array}$ & Cluster RCT & $\begin{array}{l}\text { TBA training in antepartum, intrapartum, } \\
\text { postpartum, and neonatal care; distribution of } \\
\text { clean delivery kits; referral for emergency } \\
\text { obstetrical care. }\end{array}$ & $\begin{array}{l}\text { Lady health workers also trained } \\
\text { to support TBA and link } \\
\text { community-health center } \\
\text { services. }\end{array}$ & $74 \%$ & $\begin{array}{l}\text { A) } 10114 \text {; } \\
\text { B) } 9443\end{array}$ & $\begin{array}{l}\text { 1) PMR; } \\
\text { 2) NMR; } \\
\text { 3) SBR }\end{array}$ & $\begin{array}{l}\text { 1) aOR 0.71 } \\
\text { (0.62-0.83); } \\
\text { 2) aOR } 0.70 \\
\text { (0.59-0.82); } \\
\text { 3) aOR 0.69 } \\
\text { (0.57-0.83) }\end{array}$ \\
\hline \multicolumn{10}{|c|}{ Excluded from present review -Primary intervention was neonatal resuscitation } \\
\hline $\begin{array}{l}\text { Carlo et al } \\
\text { [68]. }\end{array}$ & $\begin{array}{l}2005- \\
2007\end{array}$ & $\begin{array}{l}\text { Argentina, } \\
\text { DR Congo, } \\
\text { Guatamala, } \\
\text { India, } \\
\text { Pakistan, } \\
\text { Zambia }\end{array}$ & $\begin{array}{l}\text { Before-after } \\
\text { study }\end{array}$ & $\begin{array}{l}\text { training of community birth attendants (TBAs, } \\
\text { nurses) in WHO Essential Newborn Care, } \\
\text { including basic resuscitation with bag-mask in } \\
6 \text { countries }\end{array}$ & $\begin{array}{l}\text { Clean delivery, thermal } \\
\text { protection, breastfeeding, } \\
\text { kangaroo care }\end{array}$ & $\begin{array}{l}78 \% \text { of births } \\
\text { (post) }\end{array}$ & $\begin{array}{l}\text { A) } 22,626 \text {; } \\
\text { B) } 35,017\end{array}$ & $\begin{array}{l}\text { 1) PMR; } \\
\text { 2) SBR; } \\
\text { 3) ENMR }\end{array}$ & $\begin{array}{l}\text { 1) RR 0.85 } \\
\text { (0.70-1.02); } \\
\text { 2) RR 0.69 } \\
\text { (0.54-0.88); } \\
\text { 3) RR 0.99 } \\
\text { (0.81-1.22) }\end{array}$ \\
\hline
\end{tabular}


Table 6 Individual studies of the effect of traditional birth attendant training in intrapartum care on perinatal-neonatal mortality (Continued)

\begin{tabular}{|c|c|c|c|c|c|c|c|c|c|}
\hline $\begin{array}{l}\text { Kumar et al } \\
\text { [63] }\end{array}$ & ns & Rural India & $\begin{array}{l}\text { Quasi- } \\
\text { experimental }\end{array}$ & $\begin{array}{l}\text { TBAs trained in "advanced" resuscitation with } \\
\text { suction and bag-mask vs. usual mouth-mouth } \\
\text { resuscitation }\end{array}$ & & $\begin{array}{l}\text { TBAs } \\
\text { delivered } \\
92 \% \text { of } \\
\text { babies at } \\
\text { home }\end{array}$ & $\begin{array}{l}\text { A) } 964 \text {; } \\
\text { B) } 884\end{array}$ & $\begin{array}{l}\text { 1) "asphyxia" } \\
\text { mortality; } \\
\text { 2) PMR }\end{array}$ & $\begin{array}{l}\text { 1) RR } 0.30 \\
(0.11-0.81) \text {; } \\
\text { 2) RR } 0.82 \\
(0.56-1.19)\end{array}$ \\
\hline $\begin{array}{l}\text { Daga et al } \\
\text { [87] }\end{array}$ & 1988 & Rural India & Before-after & $\begin{array}{l}\text { TBA training in basic mouth-to -mouth } \\
\text { breathing }\end{array}$ & $\begin{array}{l}\text { Management of low birth } \\
\text { weight, hypothermia; transport } \\
\text { and referral of high risk babies } \\
\text { to hospital }\end{array}$ & $90 \%$ & $\begin{array}{l}\text { A) } 321 \text {; } \\
\text { B) } 660\end{array}$ & $\begin{array}{l}\text { 1) PMR; } \\
\text { 2) NMR; } \\
\text { 3) SBR }\end{array}$ & $\begin{array}{l}\text { 1) RR } 0.59 \\
\text { (0.32-1.09); } \\
\text { 2) RR } 0.39 \\
\text { (0.21-0.69); } \\
\text { 3) RR } 0.49 \\
(0.16,1.50)\end{array}$ \\
\hline Gill et al[67] & 2006 & Rural Zambia & Cluster RCT & $\begin{array}{l}\text { Training of TBAs in a modified neonatal } \\
\text { resuscitation program (NRP) w/resuscitator } \\
\text { facemask }\end{array}$ & $\begin{array}{l}\text { prevention of hypothermia, } \\
\text { antibiotic treatment and } \\
\text { facilitated referral for } \\
\text { presumptive neonatal sepsis }\end{array}$ & uncertain & $\begin{array}{l}\text { A) } 2007 \\
\text { B) } 1552\end{array}$ & $\begin{array}{l}\text { 1) NMR; } \\
\text { 2) "asphyxia" } \\
\text { mortality }\end{array}$ & $\begin{array}{l}\text { 1) aRR } 0.55 \\
(0.33-0.90) \text {; } \\
\text { 2) aRR } 0.37 \\
(0.17-0.81)\end{array}$ \\
\hline $\begin{array}{l}\text { Azad et al } \\
{[88]}\end{array}$ & 2004 & $\begin{array}{l}\text { Rural } \\
\text { Bangladesh }\end{array}$ & $\begin{array}{l}\text { Cluster RCT, } \\
\text { factorial } \\
\text { design }\end{array}$ & $\begin{array}{l}\text { Intervention arm: Training of TBAs in neonatal } \\
\text { resuscitation with bag-valve mask, with } \\
\text { subsequent retraining; Control arm: Training } \\
\text { of TBAs in mouth-to-mouth resuscitation }\end{array}$ & $\begin{array}{l}\text { Intervention and control: Clean } \\
\text { delivery, danger signs, } \\
\text { emergency preparedness, facility } \\
\text { referral. Women's participatory } \\
\text { groups in half of clusters }\end{array}$ & $\begin{array}{l}\sim 20 \% \text { of } \\
\text { home } \\
\text { deliveries in } \\
\text { both study } \\
\text { arms }\end{array}$ & $\begin{array}{l}\text { A) } 13195 ; B) \\
12519\end{array}$ & ENMR & $\begin{array}{l}\text { 1) RR } 0.95 \\
\text { (0.75-1.21) }\end{array}$ \\
\hline
\end{tabular}


level. The two trials $[65,66]$ were not pooled in the Cochrane analysis because of differences in study design.

Since the Cochrane evaluation [61], 3 additional trials have reported the effects of TBA training on perinatal or neonatal mortality $[67,68,88]$ but these trials focused primarily on neonatal resuscitation and are assessed in the paper regarding neonatal resuscitation [24][88].

\section{Overall level of evidence}

The CHERG-adapted GRADE approach and Rules for Evidence Review were applied to assess the overall quality of evidence for packages of childbirth care [17] (tables 5,7 ). The quality of evidence for BEmOC or $\mathrm{CEmOC}$ was very low. No studies were identified of $\mathrm{BEmOC}$ or $\mathrm{CEmOC}$ as an isolated package that were usable to estimate a cause-specific neonatal mortality or an all-cause neonatal mortality effect. Nine low-grade observational studies or historical data were identified with information relevant to the effect of emergency obstetric care packages, however, these were insufficient to derive a cause-specific mortality effect. For the effect of skilled birth attendance alone on intrapartum-related neonatal deaths, 10 studies (8 observational, 2 quasiexperimental) were identified of community skilled birth attendants and there were sufficient events meeting CHERG criteria (>50) [17], however, the overall quality of evidence was low, and there were limited cause-specific mortality data. Furthermore, the studies were primarily of community midwife training, and the comparison (baseline) was a setting where skilled birth attendants already provided childbirth care, and did not reflect a counterfactual without any skilled care at birth. Therefore for all three of these intervention packages, expert opinion was obtained to derive effect estimates.

For TBA training, there were two previous meta-analyses including one cRCT. The overall level of evidence was low, and the GRADE recommendation was conditional given the limited, heterogeneous evidence, and that the intervention effectiveness is likely to be highly context specific $[34,35]$. Therefore no Delphi process was conducted to estimate the effect of TBAs on neonatal mortality.

\section{Results of Delphi process}

In view of the low quality of evidence identified, a Delphi was undertaken [17]. The expert Delphi form included relevant data from the literature review (Additional File 2). A total of 21 experts participated, with representation from South Asia, Africa, Western Europe, North America, and Latin America/Caribbean. Consensus was reached in the first round for three questions (Questions 1, 2, 5), and after the $2^{\text {nd }}$ round for the remaining four questions (Questions 3, 4, 6, 7).

The Delphi expert panel consensus was that skilled childbirth care alone would avert 25\% (range 5-65\%, IQR $15-30 \%$ ) of intrapartum-related neonatal deaths compared with no skilled care (figure 8). Basic and comprehensive emergency obstetric care was estimated to

Table 7 GRADE summary table for the impact of traditional birth attendant training in intrapartum care on perinatalneonatal outcomes

\begin{tabular}{|c|c|c|c|c|c|c|c|c|c|}
\hline \multirow[b]{3}{*}{$\begin{array}{l}\text { No of } \\
\text { studies }\end{array}$} & \multicolumn{4}{|c|}{ Study Quality } & \multicolumn{5}{|c|}{ Summary of Findings } \\
\hline & \multirow[b]{2}{*}{ Design } & \multirow[b]{2}{*}{ Limitations } & \multicolumn{2}{|l|}{ Directness } & \multicolumn{2}{|c|}{$\begin{array}{l}\text { Endline/ } \\
\text { Intervention }\end{array}$} & \multicolumn{3}{|c|}{$\begin{array}{l}\text { Baseline/ } \\
\text { Control }\end{array}$} \\
\hline & & & $\begin{array}{l}\text { Generalizability to } \\
\text { Population of } \\
\text { Interest }\end{array}$ & $\begin{array}{l}\text { Generalizability of } \\
\text { intervention of } \\
\text { interest }\end{array}$ & Events & Births & Events & Births & $\begin{array}{l}\text { Relative } \\
\text { Risk }(95 \% \\
\mathrm{Cl})\end{array}$ \\
\hline \multicolumn{10}{|c|}{ Neonatal Mortality(AIl Cause): Low outcome specific quality } \\
\hline $1[65]$ & $\begin{array}{l}\text { Cluster } \\
\text { RCT }\end{array}$ & & Direct, rural LIC & Yes & 340 & 9710 & 439 & 8989 & $\begin{array}{c}\mathrm{aOR} 0.70 \\
(0.59-0.82)\end{array}$ \\
\hline $1[74]$ & $\begin{array}{l}\text { Cross- } \\
\text { sectional }\end{array}$ & Low quality & Direct, rural LIC & Yes & 23 & 909 & 34 & 119 & $\begin{array}{l}\text { RR } 0.60 \\
(N S)\end{array}$ \\
\hline $1[86]$ & $\begin{array}{l}\text { Before- } \\
\text { after }\end{array}$ & $\begin{array}{l}\text { Low quality before- } \\
\text { after, improved } \\
\text { surveillance post }\end{array}$ & Direct, rural LIC & & 15 & 445 & 23 & 383 & $\begin{array}{l}\text { RR } 0.66 \\
\text { (NS) }\end{array}$ \\
\hline \multicolumn{10}{|c|}{ Perinatal Mortality(All Cause): Low outcome specific quality } \\
\hline $1[65]$ & $\begin{array}{l}\text { Cluster } \\
\text { RCT }\end{array}$ & & Direct, rural LIC & Yes & 823 & 9710 & 1077 & 8989 & $\begin{array}{l}\text { aOR } 0.71 \\
(0.62-0.83)\end{array}$ \\
\hline $1[86]$ & $\begin{array}{l}\text { Before- } \\
\text { after }\end{array}$ & $\begin{array}{l}\text { Low quality before- } \\
\text { after, improved } \\
\text { surveillance post }\end{array}$ & Direct, rural LIC & Yes & 99 & 1220 & 29 & 398 & $\begin{array}{l}\text { RR } 0.92 \\
\text { (NS) }\end{array}$ \\
\hline
\end{tabular}




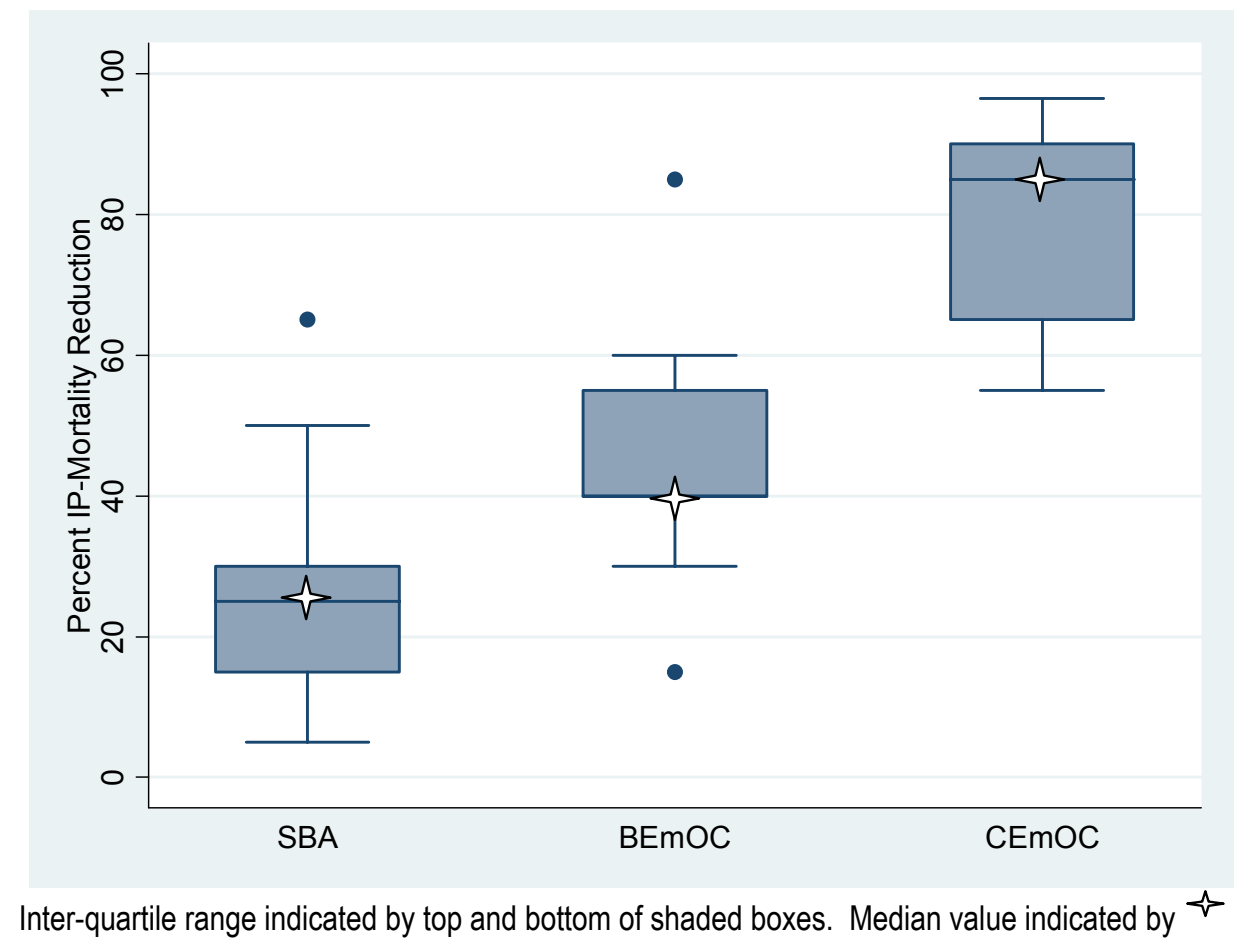

Figure 8 Box plot of Delphi expert opinion effect on intrapartum-related neonatal deaths of: Skilled attendance alone, Basic Emergency Obstetric care and Comprehensive Emergency Obstetric Care (21 experts). Legend: Inter-quartile range indicated by top and bottom of shaded boxes. Median value indicated by.

avert $40 \%$ (range $15-85 \%$, IQR $40-52.5 \%$ ), and $85 \%$ (range $55-96.5 \%$, IQR $67.5-87.5 \%$ ), of neonatal deaths due to intrapartum events, respectively.

\section{Discussion}

There are 2 million deaths each year resulting from childbirth - 814,000 intrapartum related neonatal deaths, over 1 million intrapartum stillbirths and a significant proportion of the world's 352,000 maternal deaths. Skilled childbirth care is recommended as a universal right to reduce these deaths, yet there is limited mortality evidence of the effect of childbirth care packages. The mismatch between the size of the problem and the quality of the useable evidence is stark. Our primary finding, and the main limitation of our review, is the lack of high or even moderate quality evidence of the effect of childbirth care on neonatal mortality, particularly in low and middle-income countries where the impact would be the greatest. There are a number of reasons for this low level of evidence including the challenges of ethical approval for RCTs testing care that is already considered standard, variations in obstetric packages evaluated, and inconsistencies in outcome measurement.

The variation in terminology surrounding "birth asphyxia" is a key limitation. Consistent case definitions are required; we have used the terminology "intrapartum- related" to classify neonatal deaths due to childbirthrelated complications in term infants, however despite recent improvements in clarity, many of the studies identified were older and outcome definitions varied. Furthermore, in settings where the majority of neonatal deaths occur in homes, and outside of vital registration, ascertaining cause of death must often rely on verbal autopsy, which varies with respect to tools, definitions, and hierarchies used. Consistent use of such verbal autopsy tools, and more importantly the hierarchies, is critical [69]. Finally there is a paucity of data from resource-limited settings on intrapartum-related neonatal morbidity, such as neonatal encephalopathy, which requires regular neurologic assessment and is not possible for the majority of newborns in LMIC who are born at home.

The skilled birth attendance studies which we identified were heterogeneous with varying coverage and provider skill levels, and likely underestimated the effect for several reasons. First, the results for the before-after studies reflect that of additional midwife training, since at baseline midwives were already conducting deliveries in the community and attending deliveries, so the baseline effect is not zero. In Matlab, Bangladesh, the magnitude of the effect in the intervention vs. comparison villages was diluted by the low coverage of midwives at birth (only 25\%)[50]. Furthermore, in many communities, 
formally trained midwives are only sought for complicated deliveries where the baby is already compromised and could only have been saved by emergency obstetric care, which may not be available.

Given the lack of cause-specific mortality evidence, we followed the LiST rules based on GRADE, and the effect of the 3 obstetric care packages was estimated using Delphi expert consensus [17]. We included a variety of experts with wide geographic representation (geographic region, low-middle and high income settings) and range of expertise and background (clinical, epidemiology, obstetrics, neonatology). Consensus was reached within an IQR of $30 \%$. However, any expert opinion process is clearly limited, and far from ideal.

Nonetheless, the potential for major mortality reductions with skilled intrapartum care, particularly due to intrapartum-related neonatal deaths, is widely accepted and consistent with historical data from the UK, Finland [1], and Malaysia [40]. Whilst the lack of RCT evidence for the provision or non-provision of childbirth care is understandable, given that it would be unethical to conduct such trials, the dearth of observational studies of quality improvement of childbirth care assessing its effect on neonatal mortality is disappointing and a clear priority for more research. The few significant, large intervention trials of direct relevance for establishing mortality effect estimates were those of community midwife training, EmOC training, and individual interventions to improve labor monitoring and interventions (such as use of the partograph or fetal monitoring) that are reviewed in detail in two other publication supplements $[10,20,21]$. In some studies, there were specific missed opportunities to collect relevant perinatal outcome data. The QUARITE trial, a cluster-randomized trial of quality improvement in obstetric care via emergency obstetric care training (ALARM) and maternal death reviews, is presently underway and has perinatalneonatal mortality as a secondary outcome [70]. This, and hopefully many more such evaluations, will help to fill a critical information gap.

For the 60 million women who deliver at home worldwide, achieving universal skilled birth attendance may require decades, and in the meantime many preventable deaths occur each year, primarily at community level [71]. TBAs attend up to $40 \%$ of births in South Asia, while the majority of home births in Africa are unattended [35]. The evidence for TBA training programs is of low quality and heterogeneous $[60,61,72,73]$ and their role remains controversial. However one recent cRCT which emphasized partnership of TBAs with community health workers and links with the formal health system yielded promising reductions in stillbirth and neonatal mortality [65]. Early recognition of obstetric complications, including obstructed labor, and higher referral rates for emergency obstetric care were observed in this trial, and would presumably be associated with reductions in intrapartum-related injury. Several other studies have evaluated the impact of TBA training on obstetric danger sign recognition and referral $[66,74]$; a meta-analysis reported a small, positive association between training and TBA referral-maternal health service utilization [72]. Given that the skills, role and training of the TBA may vary widely between regions and communities, and that the quality of evidence regarding training effectiveness is low and heterogeneous, the GRADE recommendation for implementation is presently conditional [35] and we did not attempt to estimate the effect size. However, the potential for TBAs to integrate and partner with the formal health system is promising, and requires further evaluation at scale and in varying contexts.

During the 1990s, the coverage of skilled birth attendance in Sub-Saharan Africa and South Asia increased little, but recent years have seen increases in a few countries. A contributor to the increasing coverage has included demand-side financing (eg voucher schemes or conditional cash transfers in India [75,76]), eliminating user fees (eg Ghana [77] and South Africa [78]) and the introduction of health insurance schemes (eg, Mauritania [79]), as reviewed recently [80]. Furthermore, innovative strategies to increase the supply of obstetric care have emerged, including task-shifting and the use of non-physician clinicians [10]. In Mozambique, assistant medical officers (técnicos de cirurgia) perform Caesarean section with no difference in complications or mortality rates compared to obstetricians $[81,82]$. Training of non-physician clinicians has been prioritized in Ethiopia, Malawi, Zambia and Mozambique, in order to fill the human resource gap. In South Asia, task shifting has involved training general practitioners, nurses and medical officers in obstetrics and anesthesia to expand coverage of EmOC [10]. Increasing the coverage of skilled obstetric care, particularly to reach the poorest, requires creative demand and supply side strategies, with sustained political and financial commitment by governments.

\section{Conclusion}

While skilled obstetrical care is the standard of care in high income countries, the quality of evidence of the impact of childbirth care packages on intrapartumrelated neonatal mortality applicable to low-income settings is low. Given the lack of epidemiologic evidence, expert opinion was used and is rated as very low quality. Our results suggest the following effectiveness on intrapartum-related neonatal deaths: 1) skilled childbirth care alone, 25\%; 2) BEmOC, 40\%; 3) CEmOC, 85\% (table 8). Using LiST with these effect estimates, we estimate that a total of 591,000 lives of those currently dying from intrapartum related causes ("birth asphyxia", 814,000) 
Table 8 Cause-specific mortality effect and GRADE of the estimates for obstetric care packages on intrapartum-related neonatal deaths

\author{
Effect of Comprehensive Emergency Obstetric Care \\ Cause specific mortality to act on: \\ Intrapartum related neonatal deaths \\ Quality of input evidence: \\ Very Low - effect estimates derived from Delphi panel consensus \\ Low quality supporting evidence (8 observational, 1 quasi-experimental) \\ GRADE recommendation \\ Strong, based on clear biological mechanism \\ Cause specific effect and range: \\ Reduction in intrapartum related neonatal deaths: $85 \%$; IQR $67.5-87.5 \%$
}

Limitations of the evidence:

Evidence without cause-specific mortality effect, and with varying content of packages and varying contexts for evaluation. Only one quasi experimental design study identified

Effect of Basic Emergency Obstetric Care

Cause specific mortality to act on:

Intrapartum related neonatal deaths

Quality of input evidence:

Very Low - effect estimates derived from Delphi panel consensus

No studies identified specifically of BEmOC with perinatal health outcomes reported

GRADE recommendation

Strong based on clear biological mechanism

Cause specific effect and range:

Reduction in intrapartum related neonatal deaths: $40 \%$; IQR $40-52.5 \%$

Limitations of the evidence:

No evidence available regarding effect of this specific package, even from observational designs.

\author{
Effect of Skilled Childbirth Care \\ Cause specific mortality to act on: \\ Intrapartum related neonatal deaths \\ Quality of input evidence: \\ Very low - effect estimates derived from Delphi panel consensus \\ Low quality supporting evidence (2 Quasi-experimental, 8 observational)
}

\title{
GRADE recommendation
}

Strong

Cause specific effect and range:

Reduction in intrapartum related neonatal deaths: $25 \%$; IQR $15-30 \%$

Limitations of the evidence:

Single study with cause-specific mortality effect. For the studies identified the content of the packages tested and the contexts for evaluation and evaluation designs were variable

Effect of Trained Traditional Birth Attendants

Quality of input evidence:

Low quality supporting evidence ( $3 \mathrm{CRCT}, 1$ quasi-experimental, 5 observational)

GRADE recommendation

Conditional, dependent on local context and health system

Cause specific effect and range:

Not estimated for LiST since GRADE recommendation is conditional

Limitations of the evidence:

Supporting evidence without cause-specific mortality effect, and with varying content of packages and varying contexts for evaluation. 5 studies primarily of TBA training in neonatal resuscitation that is NOT included as part of the estimate for childbirth care package 
could be saved by providing universal access to comprehensive obstetric care. This estimate is conservative as comprehensive obstetric care would also be expected to reduce deaths from other causes of neonatal death, notably infections and preterm birth. In addition a significant proportion of maternal deaths and 1 million stillbirths could likely be saved with intrapartum interventions [32,83-85]

The potential for major mortality impact emphasizes the urgent need to invest in childbirth care, improving services for those already giving birth in facilities, and reaching the 60 million women giving birth outside facilities. Roles and impact of training other cadres, such as TBAs, to link mothers with obstetric care requires further evaluation. The lack of data, even descriptive studies, to assess the effectiveness of these UN recommended packages of childbirth care highlights the need for more evaluation. Programmatic planning is required to assess the impact and cost of various packages and implementation strategies in varying contexts, and to strategize how best to close equity gaps for rural, poor families and how to close quality gaps that cost the lives of many women and babies at birth.

\section{Additional material}

Additional file 1 : is an excel sheet that contains fives sheets each of which has a table presenting extraction criteria and outputs for studies used in the meta-analysis.

Additional File 2: is word document that contains the Delphi form used in the Delphi process and as well as background information and appendices that were provided to the Delphi participants.

\section{List of abbreviations used}

$\mathrm{BEmOC}=$ Basic Emergency Obstetric Care; $\mathrm{CEmOC}=$ Comprehensive Emergency Obstetric Care; SBA= Skilled Birth Attendant; TBA= Traditional Birth Attendant; $\mathrm{WHO}=$ World Health Organization; $\mathrm{CHERG}=$ Child Health Epidemiology Reference Group; $\mathrm{GBD}=$ Global Burden of Disease; $\mathrm{PMR}=$ perinatal mortality rate; $\mathrm{NMR}=$ neonatal mortality rate; $\mathrm{ENMR}=$ early neonatal mortality rate

\section{Acknowledgements and funding}

We thank the members of the Delphi Expert Consensus team (alphabetical order) J Belizan, S Bergstrom, S Bhutta, E Bocaletti, G Darmstadt, S Fawcus, R Goldenberg, J Hofmeyr, H Blencowe, J Lawn, AC Lee, M Mathai, N Moran, P Okong, R Pattinson, B Peterson, C Ronsmans, W Steinberg, G Theron, A Weeks, and S Zaidi.

This work was supported by the Bill \& Melinda Gates Foundation through a grant to US Fund for UNICEF for work on LiST and to Saving Newborn Lives programme of Save the Children.

This article has been published as part of BMC Public Health Volume 11 Supplement 3, 2011: Technical inputs, enhancements and applications of the Lives Saved Tool (LiST). The full contents of the supplement are available online at http://www.biomedcentral.com/1471-2458/11?issue=\$3.

\section{Author details}

1Johns Hopkins Bloomberg School of Public Health, Department of International Health, Baltimore MD, USA. ${ }^{2}$ Department of Newborn Medicine, Brigham and Women's Hospital, Boston, MA, USA. ${ }^{3}$ London School of Tropical Medicine and Hygiene, London, UK. "Family Health Division, Global
Health Program, Bill and Melinda Gates Foundation, Seattle WA, USA. ${ }^{5}$ MRC Maternal and Infant Health Care Strategies Research unit, University of Pretoria, South Africa. ${ }^{6}$ Grey's Hospital, KwaZulu-Natal, South Africa. ${ }^{7}$ University of the Witwatersrand and East London Hospital Complex, South Africa. ${ }^{8}$ Jinnah Postgraduate Medical Center and the Aga Khan University, Karachi, Pakistan. ${ }^{9}$ Saving Newborn Lives/Save the Children.

\section{Authors' contributions}

$A C L, J L, G L D, R H$ undertook the searches and abstraction. $A C L, S C, J L, G L D$, and $\mathrm{HB}$ undertook the meta analyses. $A C L, J L, H B, N M, S B$ and GLD organised the Delphi process. $A C L$ and $J$ provided the initial draft of the paper and all authors contributed. All authors read and approved the final manuscript.

\section{Competing interests}

The authors declare that they have no competing interests.

Published: 13 April 2011

\section{References}

1. Piekkala P, Erkkola R, Kero P, Tenovuo A, Sillanpaa M: Declining perinatal mortality in a region of Finland, 1968-82. Am J Public Health 1985, 75(2):156-160.

2. Unicef: State of the World's Children 2009. Maternal and Newborn Health New York, NY: UNICEF; 2009.

3. Lawn JE, Lee AC, Kinney M, Sibley L, Carlo WA, Paul VK, Pattinson R, Darmstadt GL: Two million intrapartum-related stillbirths and neonatal deaths: where, why, and what can be done? Int J Gynaecol Obstet 2009, 107(Suppl 1):S5-18-S19.

4. Child Health Epidemiology Reference Group of WHO and UNICEF, Black RE, C S, Johnson HL, Lawn JE, Rudan I, Bassani DG, Jha P, Campbell H, Walker CF, Cibulskis R, Eisele T, Liu L, Mathers C: Global, regional, and national causes of child mortality in 2008: a systematic analysis. Lancet 2010, 375(9730):1969-1987.

5. Lawn J, Shibuya K, Stein C: No cry at birth: global estimates of intrapartum stillbirths and intrapartum-related neonatal deaths. Bull World Health Organ 2005, 83(6):409-417.

6. Organization WH: The World Health Report 2005- make every mother and child count. Geneva, Switzerland: World Health Organization; 2005.

7. Maulik PK, Darmstadt GL: Childhood disability in low- and middle-income countries: overview of screening, prevention, services, legislation, and epidemiology. Pediatrics 2007, 120(Suppl 1):S1-55.

8. Hogan MC, FK K, Naghavi M, Ahn SY, Wang M, Makela SM, Lopez AD, Lozano R, Murray CJ: Maternal mortality for 181 countries, 1980-2008: a systematic analysis of progress towards Millennium Development Goal 5. Lancet 2010, 375(9726):1609-1623.

9. Li XF, F J, Kotelchuck M, Glover LH: The postpartum period: the key to maternal mortality. IJGO 1996, 54(1):1-10.

10. Hofmeyr GJ, Haws RA, Bergstrom S, Lee AC, Okong P, Darmstadt GL, Mullany LC, Oo EK, Lawn JE: Obstetric care in low-resource settings: what, who, and how to overcome challenges to scale up? Int J Gynaecol Obstet 2009, 107(Suppl 1):S21-44-S44-25.

11. Hussein J, C S: Message in a bottle: sinking in a sea of safe motherhood concepts. Health Policy Plan 2005, 73:294-302.

12. Safe Motherhood: Providing Emergency Obstetric and Neonatal Care to All in Need. [http://www.unfpa.org/public/home/mothers/pid/4385].

13. $\mathrm{WHO}, \mathrm{ICM}, \mathrm{FIGO}$ : Making pregnancy safer: the critical role of the skilled attendant. Geneva: World Health Organization;WHO DoRHaR 2004.

14. WHO, Unicef, AMDD: Monitoring emergency obstetric care: a handbook. Geneva, Switzerland: WHO; 2009, 1-164.

15. Organization WH: Traditional birth attendants: a joint WHO/UNICEF/ UNFPA statement. Geneva: World Health Organization; 1992

16. Campbell OM, G W, LMSSsg: Strategies for reducing maternal mortality: getting on with what works. Lancet 2006, 368:1284-1299.

17. Walker N, Fischer-Walker C, Bryce J, Bahl R, Cousens S, CHERG Review Groups on Intervention Effects: Standards for CHERG reviews of intervention effects on child survival. Int J Epidemiol 2010, 39(Supplement 1):i21-31.

18. Schunemann HJ, Oxman AD, Brozek J, Glasziou P, Bossuyt P, Chang S, Muti $P$, Jaeschke $R$, Guyatt GH: GRADE: assessing the quality of evidence for diagnostic recommendations. ACP J Club 2008, 149(6):2. 
19. Bhutta ZA, Darmstadt GL, Haws RA, Yakoob MY, Lawn JE: Delivering interventions to reduce the global burden of stillbirths: improving service supply and community demand. BMC Pregnancy Childbirth 2009, 9(Suppl 1):S7.

20. Darmstadt GL, Yakoob MY, Haws RA, Menezes EV, Soomro T, Bhutta ZA: Reducing stillbirths: interventions during labour. BMC Pregnancy Childbirth 2009, 9(Suppl 1):S6.

21. Haws RA, Yakoob MY, Soomro T, Menezes EV, Darmstadt GL, Bhutta ZA: Reducing stillbirths: screening and monitoring during pregnancy and labour. BMC Pregnancy Childbirth 2009, 9(Suppl 1):S5

22. Haws RA, Thomas AL, Bhutta ZA, Darmstadt GL: Impact of packaged interventions on neonatal health: a review of the evidence. Health Policy Plan 2007, 22(4):193-215.

23. Blencowe Hannah, C S, Mullany Luke C, Lee Anne CC, Kerber Kate, Wall Steve, Darmstadt Gary L, Lawn Joy E: Clean birth and postnatal care practices to reduce neonatal deaths from sepsis and tetanus. BMC Pregnancy Childbirth 2010, Submitted for publication.

24. Lee AC, Wall S, Cousens S, Carlo W, Niermeyer S, Keenan W, Darmstadt G, Bhutta Z, Lawn JE: Neonatal resuscitation and simple immediate newborn care for the prevention of neonatal deaths. BMC Public Health 2011, Submitted for publication.

25. Cousens S, B H, Gravett M, Lawn JE: Antibiotics for pre-term pre-labour rupture of membranes: prevention of neonatal deaths due to complications of pre-term birth and infection. Int J Epidemiol 2010, 39(Supp 1):i134-143.

26. Mwansa-Kambafwile J, C S, Hansen T, Lawn JE: Antenatal steroids in preterm labour for the prevention of neonatal deaths due to complications of preterm birth. Int J Epidemiol 2010, 39(Suppl 1): i122-133.

27. Lawn JE, Wilczynska-Ketende K, Cousens SN: Estimating the causes of 4 million neonatal deaths in the year 2000. Int J Epidemiol 2006, 35(3):706-718.

28. Sarnat HB, Sarnat MS: Neonatal encephalopathy following fetal distress. A clinical and electroencephalographic study. Arch Neurol 1976, 33(10):696-705.

29. Finer NN, Robertson CM, Richards RT, Pinnell LE, Peters KL: Hypoxicischemic encephalopathy in term neonates: perinatal factors and outcome. J Pediatr 1981, 98(1):112-117.

30. Leviton A, Nelson KB: Problems with definitions and classifications of newborn encephalopathy. Pediatr Neurol 1992, 8(2):85-90.

31. Committee on Fetus and Newborn AAoP, Committee on Obstetric Practice, American College of Obstetricians and Gynecologists: Use and Abuse of the Apgar Score. Pediatrics 1996, 98:141-142.

32. Yakoob MY, Ali MA, Ali MU, Lawn JE, Bhutta ZA: The effect of providing obstetric care services (skilled birth attendants, basic and comprehensive emergency obstetric care) in preventing stillbirths and perinatal mortality. BMC Public Health 2011, Submitted for publication.

33. Lee A, Lawn J: CHERG Global Burden of Disease Neonatal Encephalopathy Estimates 2009. Boston MA; 2009.

34. Lawn JE, Kinney M, Lee AC, Chopra M, Donnay F, Paul VK, Bhutta ZA, Bateman M, Darmstadt GL: Reducing intrapartum-related deaths and disability: can the health system deliver? Int J Gynaecol Obstet 2009, 107(Suppl 1):S123-140-S140-122.

35. Darmstadt GL, Lee AC, Cousens S, Sibley L, Bhutta ZA, Donnay F, Osrin D, Bang A, Kumar V, Wall SN, et al: 60 Million non-facility births: who can deliver in community settings to reduce intrapartum-related deaths? Int J Gynaecol Obstet 2009, 107(Suppl 1):S89-112.

36. Dalkey N: DELPHI.Organization R 1967, 10.

37. Ronsmans C, Chowdhury ME, Koblinsky M, Ahmed A: Care seeking at time of childbirth, and maternal and perinatal mortality in Matlab, Bangladesh. Bull World Health Organ 2010, 88(4):289-296.

38. Hounton S, Byass P, Brahima B: Towards reduction of maternal and perinatal mortality in rural Burkina Faso: communities are not empty vessels. Glob Health Action 2009, 2.

39. Hounton S, Sombie I, Meda N, Bassane B, Byass P, Stanton C, De Brouwere $V$ : Methods for evaluating effectiveness and cost-effectiveness of a Skilled Care Initiative in rural Burkina Faso. Trop Med Int Health 2008, 13(Suppl 1):14-24.

40. Koblinsky M, Campbell O, Heichelheim J: Organizing delivery care: what works for safe motherhood? Bull World Health 1999, 77:399-406.
41. Draycott T, Sibanda T, Owen L, Akande V, Winter C, Reading S, Whitelaw A: Does training in obstetric emergencies improve neonatal outcome? Bjog 2006, 113(2):177-182.

42. Emond A, Pollock J, Da Costa N, Maranhao T, Macedo A: The effectiveness of community-based interventions to improve maternal and infant health in the Northeast of Brazil. Rev Panam Salud Publica 2002, 12(2):101-110.

43. McCord C, P R, Arole S, Arole R: Efficient and effective emergency obstetric care in a rural Indian community where most deliveries are at home. Int J Gynaecol Obstet 2001, 75:297-307.

44. Berglund A, L-C H, Bacci A, Blyumina A, Lindmark G: Successful implementation of evidence-based routines in Ukrainian maternities. Acta Obstet Gynecol Scand 2010, 89(2):230-237.

45. Korhonen J, Kariniemi V: Emergency cesarean section: the effect of delay on umbilical arterial gas balance and Apgar scores. Acta Obstet Gynecol Scand 1994, 73(10):782-786.

46. Center for Maternal and Child Enquiries: Perinatal Mortality 2008: United Kingdom. London; 2010.

47. Rosen H, al E: Thermoregulation. BMC Public Health 2010.

48. Yan RY: How Chinese clinicians contribute to the improvement of maternity care. Int J Gynaecol Obstet 1989, 30(1):23-26.

49. Ibrahim SA, Omer MI, Amin IK, Babiker AG, Rushwan H: The role of the village midwife in detection of high risk pregnancies and newborns. Int J Gynaecol Obstet 1992, 39(2):117-122.

50. Ronsmans C, Chowdhury ME, Alam N, Koblinsky M, El Arifeen S: Trends in stillbirths, early and late neonatal mortality in rural Bangladesh: the role of public health interventions. Paediatr Perinat Epidemiol 2008, 22(3):269-279.

51. Alisjahbana A, Williams C, Dharmayanti R, Hermawan D, Kwast BE, Koblinsky M: An integrated village maternity service to improve referral patterns in a rural area in West-Java. Int J Gynaecol Obstet 1995, 48(Suppl):S83-94.

52. Hounton S, Menten J, Ouedraogo M, Dubourg D, Meda N, Ronsmans C, Byass P, De Brouwere V: Effects of a Skilled Care Initiative on pregnancyrelated mortality in rural Burkina Faso. Trop Med Int Health 2008, 13(Suppl 1):53-60.

53. Baqui AH, Darmstadt GL, Williams EK, Kumar V, Kiran TU, Panwar D, Srivastava VK, Ahuja R, Black RE, Santosham M: Rates, timing and causes of neonatal deaths in rural India: implications for neonatal health programmes. Bull World Health Organ 2006, 84(9):706-713.

54. Edmond KM, Quigley MA, Zandoh C, Danso S, Hurt C, Owusu Agyei S, Kirkwood BR: Aetiology of stillbirths and neonatal deaths in rural Ghana: implications for health programming in developing countries. Paediatr Perinat Epidemiol 2008, 22(5):430-437.

55. Andersson T, Hogberg U, Bergstrom S: Community-based prevention of perinatal deaths: lessons from nineteenth-century Sweden. Int J Epidemiol 2000, 29(3):542-548.

56. Hatt L, Stanton C, Ronsmans C, Makowiecka K, Adisasmita A: Did professional attendance at home births improve early neonatal survival in Indonesia? Health Policy Plan 2009.

57. Shankar A, Sebayang S, Guarenti L, Utomo B, Islam M, Fauveau V, Jalal F: The village-based midwife programme in Indonesia. Lancet 2008, 371(9620):1226-1229.

58. Ariawan I: Reducing Birth Asphyxia Through the Bidan di Desa Program in Cirebon, Indonesia. Jakarta, Indonesia: PATH; 2006, 1-18.

59. Matthews M, Walley R: Working with Midwives to improve Maternal Health in Rural Ghana. Canadian Journal of Midwifery Research and Practice 2004, 3(3):24-33.

60. Sibley L, Ann Sipe T: What can a meta-analysis tell us about traditional birth attendant training and pregnancy outcomes? Midwifery 2004, 20(1):51-60.

61. Sibley LM, Sipe TA, Brown CM, Diallo MM, McNatt K, Habarta N: Traditional birth attendant training for improving health behaviours and pregnancy outcomes. Cochrane Database Syst Rev 2007, , 3: CD005460.

62. Bang AT, Bang RA, Sontakke PG: Management of childhood pneumonia by traditional birth attendants. The SEARCH Team. Bull World Health Organ 1994, 72(6):897-905.

63. Kumar R: Effectiveness of training traditional birth attendants for management of asphyxia neonatorum using resuscitation equipment. Prenatal Neonatal Medicine 1998, 3:255-260. 
64. Okubagzhi GS: Fulfilling the potential of traditional birth attendants. World Health Forum 1988, 9(3):426-431.

65. Jokhio AH, Winter HR, Cheng KK: An intervention involving traditional birth attendants and perinatal and maternal mortality in Pakistan. N Engl J Med 2005, 352(20):2091-2099.

66. O'Rourke K: The effect of hospital staff training on management of obstetrical patients referred by traditional birth attendants. Int I Gynaecol Obstet 1995, 48(Suppl):S95-102.

67. Gill CJ, P-M G, Guerina NG, Kasimba J, Mulenga C, Macleod WB, Waitolo N, Knapp AB, Mirochnick M, Mazimba A, Fox MP, Sabin L, Seidenberg P, Simon JL, Hamer DH: Effect of training traditional birth attendants on neonatal mortality (Lufwanyama Neonatal Survival Project): randomised controlled study. British Medical Journal 2011, 342:d346.

68. Carlo WA, Goudar SS, Jehan I, Chomba E, Tshefu A, Garces A, Parida S, Althabe F, McClure EM, Derman RJ, et al: Newborn-care training and perinatal mortality in developing countries. N Engl J Med 2010, 362(7):614-623.

69. Lawn JE, Osrin D, Adler A, Cousens S: Four million neonatal deaths: counting and attribution of cause of death. Paediatr Perinat Epidemiol 2008, 22(5):410-416.

70. Dumont A, F P, Fraser W, Haddad S, Traore M, Diop I, Gueye M, Gaye A, Couturier F, Pasquier JC, Beaudoin F, Lalonde A, Hatem M, Abrahamowicz M.: QUARITE (quality of care, risk management and technology in obstetrics): a cluster-randomized trial of a multifaceted intervention to improve emergency obstetric care in Senegal and Mali. Trials 2009, 10:85.

71. Lawn J, Kinney M, Lee AC, Chopra M, Donnay F, Paul V, Bateman M, Bhutta Z, Darmstadt G: Reducing intrapartum-related deaths and disability: can the health system deliver? International Journal of Gynecology and Obstetrics 2009

72. Sibley L, Sipe TA, Koblinsky M: Does traditional birth attendant training improve referral of women with obstetric complications: a review of the evidence. Soc Sci Med 2004, 59(8):1757-1768.

73. Sibley LM, Sipe TA, Koblinsky M: Does traditional birth attendant training increase use of antenatal care? A review of the evidence. J Midwifery Womens Health 2004, 49(4):298-305.

74. Janowitz B, Wallace $S$, Araujo G, Araujo L: Referrals by traditional birth attendants in northeast Brazil. Am J Public Health 1985, 75(7):745-748.

75. Bhat $R$, Mavalankar $D$, Singh $P$, Singh $N$ : Maternal Health Financing in Gujarat: Preliminary Results from a Household Survey of Beneficiaries under Chiranjeevi Scheme. Ahmedabad, India: Indian Institute of Management; 2007.

76. Lahariya C: Cash incentives for institutional delivery: Linkin with antenatal and postnatal care may ensure 'continuum of care' in India. Indian Journal Community Medicine 2009, 34(1):15-18.

77. Smith KV, Sulzbach S: Community-based health insurance and access to maternal health services: evidence from three West African countries. Soc Sci Med 2008, 66(12):2460-2473.

78. Schneider P, G L: The impact of free maternal health care in South Africa. In Safe Motherhood Initiatives: Critical Issues. Oxford: Blackwell Science for Reproductive Health Matters;Berer M DRT 1999:93-101.

79. Renaudin P, Prual A, Vangeenderhuysen C, Ould Abdelkader M, Ould Mohamed Vall M, Ould El Joud D: Ensuring financial access to emergency obstetric care: three years of experience with Obstetric Risk Insurance in Nouakchott, Mauritania. Int J Gynaecol Obstet 2007, 99(2):183-190.

80. Lee AC, Lawn JE, Cousens S, Kumar V, Osrin D, Bhutta ZA, Wall SN, Nandakumar AK, Syed U, Darmstadt GL: Linking families and facilities for care at birth: what works to avert intrapartum-related deaths? Int $J$ Gynaecol Obstet 2009, 107(Suppl 1):S65-85-S86-68.

81. Pereira C, Bugalho A, Bergstrom S, Vaz F, Cotiro M: A comparative study of caesarean deliveries by assistant medical officers and obstetricians in Mozambique. BJOG 1996, 103:508-512.

82. Vaz F, Bergstrom S, Vaz M, Langa J, Bugalho A: Training medical assistants for surgery. Bull World Health 1999, 77:688-691.

83. Pattinson $R, K$ K Buchmann E, et al: Stillbirths: how can health systems deliver for mothers and babies? Lancet 2011, online March 9, 2011.

84. Lawn JE, B B, Pattinson R, et al: Where? When? Why? How to make the data count? Lancet 2011, March 9 online.

85. Bhutta ZA, Y M, Lawn JE, et al: Stillbirths: how much difference can we make and at what cost? Lancet 2011, March 9 online.
86. Greenwood A, B AK, Byass P, Greenwood BM, Snow RW, Bennett S, Hatib$N^{\prime}$ Jie AB: Evaluation of a primary health care programme in The Gambia. Journal of tropical Medicine and hygiene 1990, 93(1):58-66.

87. Daga SR, Daga AS, Dighole RV, Patil RP, Dhinde HL: Rural neonatal care: Dahanu experience. Indian Pediatr 1992, 29(2):189-193.

88. Azad K, Barnett S, Banerjee B, Shaha S, Khan K, Rego AR, Barua S, Flatman D, Pagel C, Prost A, Ellis M, Costello A: Effect of scaling up women's groups on birth outcomes in three rural districts in Bangladesh: a cluster-randomised controlled trial. Lancet 2010, 375(9721):1193-1202.

doi:10.1186/1471-2458-11-S3-S10

Cite this article as: Lee et al.: Care during labor and birth for the prevention of intrapartum-related neonatal deaths: a systematic review and Delphi estimation of mortality effect. BMC Public Health 201111 (Suppl 3):S10.

\section{Submit your next manuscript to BioMed Central and take full advantage of:}

- Convenient online submission

- Thorough peer review

- No space constraints or color figure charges

- Immediate publication on acceptance

- Inclusion in PubMed, CAS, Scopus and Google Scholar

- Research which is freely available for redistribution

Submit your manuscript at www.biomedcentral.com/submit
Ciomed Central 